\title{
THE INFANCY GOSPEL OF THOMAS FROM AN UNPUBLISHED SYRIAC MANUSCRIPT: INTRODUCTION, TEXT, TRANSLATION, AND NOTES ${ }^{1}$
}

\author{
TONY BURKE \\ YORK UNIVERSITY, TORONTO, CANADA
}

\begin{abstract}
:
The Syriac Infancy Gospel of Thomas (IGT) has been published from three manuscripts, two of which hail from the $5^{\text {th }}$ or $6^{\text {th }}$ centuries. Unfortunately, all three sources lack large sections of the text. In 1914, Paul Peeters discussed a fourth Ms (Vat. Syr. 159 from the $17^{\text {th }}$ century) preserving the entire text, but until now, that Ms has not been published. This article presents a diplomatic edition of Peeters' Ms, comparing its readings with those previously published and with another unpublished Ms very similar to the one used by Peeters. Also included are a comprehensive overview of other Syriac sources for IGT and a discussion of Peeters' theory of Syriac composition for IGT.
\end{abstract}

1 A version of this paper was presented at the 2008 Réunion de l'Association pour l'étude de la littérature apocryphe chrétienne (AELAC). My thanks to those who offered suggestions for improvement, as well as to F. Stanley Jones, Slavomír Čéplö, and Lucas van Rompay for their feedback on the Syriac text and its translation. I would also like to thank the anonymous peer reviewers who provided helpful feecback. 
Almost 100 years ago, the great Bollandist Paul Peeters revealed the existence of a manuscript from the Vatican (Vat. Syr. 159; dated 1622/23; =P) containing the Infancy Gospel of Thomas (IGT) in Syriac as an appendix to a Garshûni version of the Arabic Infancy Gospel (Arab. Gos. Inf.). ${ }^{2}$ This manuscript was used by Peeters to establish a theory of composition and transmission for the larger corpus of infancy gospels, including Arab. Gos. Inf. and the Armenian Infancy Gospel (Arm. Gos. Inf.). As for IGT, Peeters stated his belief that the gospel was composed in Syriac, but offered no proof for his assertion. He did, however, provide a French translation of several chapters from the new Ms (ch. 5-8) and revealed that it was more complete than another Syriac manuscript (W) published 50 years earlier. Until now, no-one has returned to this tantalizing find-a surprising oversight given that several scholars over the years have entertained Peeters' theory of Syriac composition for IGT.

Though both Peeters' overarching theory of composition for the infancy gospels and the related theory of Syriac composition for IGT are no longer sustainable, ${ }^{3}$ the Syriac tradition remains important for the study of IGT. And, as Peeters stated long ago, P is indeed an excellent witness to this tradition, in some ways surpassing the worth of all previously published Syriac Mss, and perhaps even all other witnesses to the infancy gospel.

\section{THE WIDER MANUSCRIPT TRADITION OF IGT}

IGT is best known to readers in the Greek form of the text made popular by Constantin von Tischendorf. He provided an edition using four previously published Mss: Dresden $A$ 187,4 Bologna Univ. 2702,5 Paris A. F. gr. 239 (2908/2279), ${ }^{6}$ and Vienna Phil. gr.

2 In Évangiles apocryphes, vol. 2, Textes et documents pour l'étude historique du Christianisme 18, ed. Charles Michel and Paul Peeters (Paris: Librairie Alphonse Picard \& Fils, 1914), see particularly p. 291-311.

${ }^{3}$ See the discussion in Tony Burke, De infantia Iesu enangelium Thomae graece, CCSA 17 (Turnhout: Brepols, 2010), 174-88.

${ }^{4}$ Published previously by Ioannis Caroli Thilo, Codex apocryphus Novi Testamenti, vol. 1, (Leipzig: Vogel, 1832), lxxiii-xci (introduction), 277-315 (text with Latin translation and notes).

5 Published previously in a diplomatic edition by Giovanni Luigi Mingarelli, "De Apocrypho Thomae Evangelio . . . epistola," in Nuova Raccolta d'opuscoli scientifici e filologici, vol. 12, ed. A. Calogiera (Venice 1764), 73-155. 
$162(144)^{7}$ - none of which are earlier than the fifteenth century. ${ }^{8}$ This form of the text, dubbed Greek A (Ga), runs nineteen chapters, culminating in the story of Jesus in the Temple from Luke 2:41-52. Ga has become the textus receptus in IGT scholarship, regularly appearing in collections of Christian Apocrypha both in Greek and in modern translation. Tischendorf also published a shorter form of the text, Greek B (Gb), from a single Ms he found on his famous visit to St. Catherine's monastery (Cod. Sinaiticus gr. $453,14 / 15^{\text {th }}$ cent.). ${ }^{9}$ In 1927 , a third Greek recension, Greek D (Gd), was published from a fifteenth-century Ms (Cod. Ath. gr. 355) by Armand Delatte. ${ }^{10}$ This version features a prologue of several episodes of the Holy Family's journey in Egypt. A fourth and final Greek recension, Greek S (Gs), was edited from a single eleventhcentury Ms (Cod. Sabaiticus 259) for my 2001 dissertation and subsequent 2010 critical edition. ${ }^{11}$ Gs is similar in style and

${ }_{6}$ Published previously first, in part, by Richard Simon, Nowvelles observations sur le texte et les versions du Nouvean Testament (1695; repr., Frankfurt am Main: Minerva, 1973) and in full by Jean Baptiste Cotelier, SS. Patrum qui temporibus apostolicis floruerunt, vol. 1, $2^{\text {nd }}$ ed. (Antwerp: Huguetanorum sumtibus, 1698), 345-46.

7 The title and extracts from chs. 1 and 2 where published in the catalogue by Peter Lambeck, Commentariorum de augustissima Bibliotheca Caesarea Vindobenensi liber septimus (Vienna: Typis M. Cosmerovii, 1675), 270-73. The IGT section of the Ms has since been lost.

8 Constantin von Tischendorf, Evangelia Apocrypha, $2^{\text {nd }}$ ed. (1 $1^{\text {st }} \mathrm{ed}$. 1853; Leipzig: Mendelsohn, 1876), 140-57. All four Mss were employed three decades earlier in Thilo's edition but Tischendorf's particular arrangement of the Mss achieved a wider audience.

9 Tischendorf, Evangelia Apocrypha, 158-63. Greek B first saw publication in Tischendorf's account of his Mt. Sinai expedition, "Rechenschaft über meine handschriftlichen Studien auf meiner wissenschaftlichen Reise von 1840 bis 1844," in Jabrbücher der Literatur 114 (Vienna: Carl Gerold Anzeigeblatt, 1846), 51-53.

10 "Évangile de l'enfance de Jacques: Manuscrit No. 355 de la Bibliothèque Nationale," in Anecdota Atheniensia, vol. 1, Textes grecs inédits relatifs à l'bistoire des religions, ed. Armand Delatte (Paris: Edouard Champion, 1927), 264-71.

${ }^{11}$ Tony Chartrand-Burke, "The Infancy Gospel of Thomas: The Text, its Origins, and its Transmission" (Ph.D. diss., University of Toronto, 2001), 101-16 and Burke, De infantia Iesu euangelium, 302-37. Gs was published subsequently in Andries G. van Aarde, "Die Griekse manuskrip van die Kindheidsevangelie van Tomas in Kodeks Sinaïtikus (Gr 453) vertaal in 
vocabulary to $\mathrm{Ga}$ but lacks several chapters (17 and 18, and ch. 10 is found between 16 and 19). The dissertation and critical edition also drew upon new Mss of each of the other three recensions, improving the texts considerably over previous editions. ${ }^{12}$

IGT is extant as well in a number of other languages. ${ }^{13}$ Tischendorf, again, published three Latin witnesses to the text: an early translation from a fifth-century fragmentary palimpsest (Vindobonensis 563; $=\mathrm{LV}$ ), ${ }^{14}$ a more recent translation related to $\mathrm{Gd}$ (Vat. lat. 4578, 14th cent.; =LT), ${ }^{15}$ and two Mss of an expanded version of the Gospel of Psendo-Matthew that incorporates the same Latin IGT found in the palimpsest (=LM). ${ }^{16}$ This older Latin tradition also lies behind a version in Irish verse dated to around 700 CE. ${ }^{17}$ Then there is a fragmentary Georgian manuscript (=Geo), ${ }^{18}$ a group of Ethiopic Mss (=Eth), ${ }^{19}$ and the Slavonic

Afrikaans" (Hervormde Teologiese Studies / HTS Theological Studies 61 [2005], 491-516, and in Reidar Aasgaard, The Childhood of Jesus: Decoding the Apocryphal Infancy Gospel of Thomas (Eugene, OR: Cascade Books, 2009), 219-42.

12 Descriptions of all the IGT Mss can be found in Burke, De infantia Iesu euangelium, 127-44, and Tony Chartrand-Burke, "The Greek Manuscript Tradition of the Infancy Gospel of Thomas" (Apocrypha 14 [2004], 129-51).

${ }^{13}$ For a comprehensive discussion of these witnesses see Burke, De infantia Iesu enangelium, 144-71.

14 Tischendorf, Evangelia Aporrypha, xliv-xlvi. Additional lines of the palimpsest were deciphered by Guy Philippart and presented in "Fragments palimpsestes latins du Vindobonensis 563 (Ve siècle?): Évangile selon S. Matthieu, Évangile de Nicodème, Évangile de l'Enfance selon Thomas" (AnBoll 90 [1972], 391-411).

15 Tischendorf, Evangelia Apocrypha, 164-80.

16 Ibid., 93-112. The LM tradition is examined also in Sever J. Voicu, "La tradition latine des Paidika," Bulletin de l'AELAC 14 (2004): 13-21.

17 Published from a single manuscript (Dublin, National Library of Ireland, $M S$ G 50) by James Carney, "Two Old Irish Poems" (Eriu 18 [1958], 1-43) and more recently by Máire Herbert and Martin McNamara, "A Versified Narrative of the Childhood Deeds of the Lord Jesus," in Apocrypha Hiberniae, t. 1: Evangelia infantiae, vol. 1, ed. Martin McNamara et al., CCSA 13 (Turnhout: Brepols, 2001), 443-83.

18 Tblisi, Cod. A 95 copied around the end of the tenth century. The text was published simultaneously in Georgian and Russian early in the twentieth century but was given wider exposure in a Latin translation by 
tradition (=Slav), which originated from a tenth- or eleventhcentury translation of Ga. ${ }^{20}$ Finally, we have the Syriac translation, one of the earliest and, some would say, the most important of the versions of IGT.

\section{THE SYRIAC TRADITION}

The Syriac IGT comes in three forms: as a separate and distinct text (designated Sa), as book four of a six-book Life of Mary collection in West Syriac script $(\mathrm{Sw})$, and incorporated in several manuscripts of another Life of Mary collection in East Syriac script (Se).

\section{Recension Sa}

The first Sa Ms came to scholars' attention in 1865 with William Wright's publication of a sixth-century Ms from the British Library in London (Add. 14484; =W). ${ }^{21}$ The Ms contains several texts related to Mary of Nazareth, beginning with the Protevangelium Jacobi

Gérard Garitte, "Le fragment géorgien de l'Évangile de Thomas" (RHE 51 [1956], 513-15).

${ }^{19}$ Found in at least 25 manuscripts of the Ta'amra 'Iyasüs (Miracles of Jesus), a large biographical work compiled from various canonical and noncanonical sources. Sylvain Grébaut, "Les miracles de Jésus: Texte éthiopien publié et traduit" (PO 12.4 [1919], 625-42) used three of the Mss for his edition of the IGT section of the Miracles.

20 The Slavonic tradition comprises six medieval manuscripts in Middle Bulgarian, Serbian, Croatian, and Russian, and ten in Ukrainian from the eighteenth/nineteenth century. For more on the Slavonic tradition see the two major studies by Aurelio de Santos Otero, Das kirchenslavische Evangelium des Thomas, PTS 6 (Berlin: De Gruyter, 1967) and Thomas Rosén, The Slavonic Translation of the Apocryphal Infancy Gospel of Thomas, Acta Universitatis Upsaliensis, Studia Slavica Upsaliensia 39 (Uppsala: Almqvist \& Wiksell International, 1997).

${ }^{21}$ William Wright, Contributions to the Apocryphal Literature of the New Testament (London: Williams \& Norgate 1865), $\omega-\curvearrowleft$ (Syriac text), 6-11 (English translation). For another overview of the publishing history of the Syriac IGT (much of it similar to Burke, De infantia Iesu enangelium), see Cornelia B. Horn and Robert R. Phenix, "Apocryphal Gospels in Syriac and Related Texts Offering Traditions about Jesus," in Jesus in apokryphen Evangelienüberlieferungen, WUNT 254, ed. Jörg Frey and Jens Schröter (Tübingen : Mohr Siebeck, 2010), 537-44. 
(Prot. Jas.), then IGT, and finishing with the Assumption of the Virgin (Assum. Vir.). The Ms represents an early effort to combine texts to create a comprehensive Life of Mary; however, in W the texts are still separate and distinct, whereas in the other IGT recensions they are woven together in a single narrative (see further below). The version of IGT found in W is somewhat shorter than the Greek textus receptus: chs. 1, 10, 17 and 18 are missing, and many of the extant chapters are shorter, except for ch. 6 which contains material absent from Tischendorf's Ga Mss but has parallels in some of the newly-published Ga Mss, as well as Gd, Gs, LT, Slav, and the early versions. The shorter form of the text that we find in Wright's Ms matches also the form of the early Latin, Ethiopic, and Georgian versions. Lucas van Rompay concluded from this that the early versions are closer in form to the original text than the Greek and related traditions (LT and Slav). ${ }^{22} \mathrm{Gs}$, for its part, was shown by Sever Voicu to be an intermediate text, standing between the early versions and the later Greek and related traditions. ${ }^{23}$

A second Sa manuscript directly related to $\mathrm{W}$ came to light in 1911. In a brief notice in Theologische Literaturzeitung, Hugo Duensing mentioned a new MS originating from Mt. Sinai that he personally donated to the Göttingen Universitätsbibliothek (Syr. 10; 5/6th cent.; =G). ${ }^{24}$ The Ms was subsequently used by Arnold Meyer in his translation of IGT for the second edition of Edgar Hennecke's Neutestamentlichen Apokryphen in 1924.25 Meyer's

22 "De ethiopische versie van het Kindsheidsevangelie volgens Thomas de Israëliet," in Enfant dans les civilisations orientales, ed. A. Théodoridès, P. Naster, and J. Riesl (Leuven: Editions Peeters, 1980), 119-32.

23 "Notes sur l'histoire du texte de l'Histoire de l'enfance de Jésus" (Apocrypha 2 [1991]: 119-32).

24 "Mitteilungen 58" (TLZ 36 [1911], 637). Sever Voicu, in his discussions of IGT, uses the siglum $\mathrm{S}^{\mathrm{r}}$, named for a collation of the Ms made for him by Frederic Rilliet.

25 "Kindheitserzählung des Thomas," in Neutestamentlichen Apokryphen, ed. Edgar Hennecke, $2^{\text {nd }}$ ed. (Tübingen: J. C. B. Mohr, 1924), 93-94. Meyer credited A. Rahlfs with providing him with a description of the contents of G. This admission led Wilhelm Baars and Jan Heldermann to suppose Meyer was neither fully aware of the contents of the Ms nor that he used it for his translation ("Neue Materielen zum Text und zur Interpretation des Kindheitsevangeliums des Pseudo-Thomas" [OrChr 77 (1993), 193 n. 10]; perhaps echoing an earlier comment by Stephen Gero, 
translation occasionally features two columns: one based on $\mathrm{Ga}$ and the other on both $\mathrm{W}$ and $\mathrm{G}$. The full extent of $\mathrm{G}$ was not revealed at the time, but readers would have seen from Meyer's text that it includes material from chs. 6-8 missing in W. G finally saw publication in a two-part 1993/1994 article by Wilhelm Baars and Jan Heldermann. ${ }^{26}$ The two offered a codicological analysis of the Ms and a collation against Wright's edition of W. G is a valuable source for the tradition, for it does contain material missing in W; however, it also suffers from some omissions of its own, most notably the absence of chs. 14, 15 and much of ch. 7. Additional pages of the Göttingen Ms were discovered recently among new finds at St. Catharine's Monastery; alas, the new pages belong not to IGT but to the text of Prot. Jas. that precedes it. ${ }^{27}$

The Vatican Ms (P) discussed by Peeters also belongs to the Sa recension. In the second of two volumes of Christian Apocrypha published in 1914, Paul Peeters drew on several childhood textsincluding Arab. Gos. Inf., Arm. Inf. Gos., and Vat. Syr. 159-to propose an expansive Syro-Arabian theory of origin for the infancy gospel traditions. According to the theory, all of the childhood stories found in these texts derive from a larger collection of legends assembled in Syriac in the fifth century. ${ }^{28}$ In the Vatican Ms, IGT appears not as part of a collection of Life of Mary texts as in $\mathrm{W}$ and $\mathrm{G}$, but as an appendix to Arab. Gos. Inf. Though Peeters did not produce an edition of the new Ms, he did mention at the time that he believed $\mathrm{P}$ to be a superior witness to IGT than the

"The Infancy Gospel of Thomas: A Study of the Textual and Literary Problems" [NovT 13 (1971), 51 n. 6]). A comparison of Meyer's 1904 translation with the translation of 1924 makes it clear that this is not the case.

26 Baars and Heldermann, "Neue Materielen."

${ }^{27}$ For photographs of Sinai SP 78 see Sebastian P. Brock, Catalogue of the Syriac Fragments (New Finds) in the Library of the Monastery of Saint Catharine, Mount Sinai (Athens: Fondation du Sinai, 1995), 73-74; for photographs of Sinai M26N see Philothée du Sinaï, Nouveaux manuscrits syriaques du Sinaï (Monastère Sainte Catharine, Archevêché du Sinaï, Pharan et Raitho) (Athens: Fondation du Sinaï, 2008), 363-65. The identification of the new pages as belonging to $G$ was made by Alain Desreumaux, "Deux anciens manuscrits syriaques d'oeuvres apocryphes dans le nouveau fonds de Sainte-Catharine du Sinaï: La Vie de la Vierge et Les Actes d'André et Mathias" (Apocrypha 20 [2009], 115-36).

${ }^{28}$ Évangiles apocryphes, xvii-xx. 
previously published Mss (W and Budge's Life of Mary Ms A, see below), principally because it included material from chapters 6-8 and 15 missing in W. He admitted that readers would find his assessment difficult to believe given the date of the Ms (17th cent.)..$^{29}$ It is unfortunate that Peeters did not provide the text of his new Syriac Ms; he did, however, provide an excerpt of chs. 5-8, translated into French with notes on variant readings from $\mathrm{W}$, the Greek and Latin Mss, and an edition of four Slavonic Mss. Another Syriac IGT Ms, until now unpublished, contains a text very similar to P. Mingana, Syr. 105 of the nineteenth-century is virtually a twin of the text from Peeters' Ms but here appears without Arab. Gos. Inf.

\section{Recension Se}

A number of chapters from the Syriac IGT are incorporated in three manuscripts of an East Syriac Life of Mary narrative. This Life of Mary (=CANT 94; BHO 643-645) was published in 1899 by Ernest A. W. Budge ${ }^{30}$ based on two manuscripts: an unnamed Ms from Alqoš (13/14th cent.) 31 and Royal Asiatic Society, Syr. 1 (dated 1569). Only the Alqoš Ms contains the IGT material, though two unpublished Mss (Mingana Syr. 502 and Mingana Syr. 122) also

\section{${ }^{29}$ Ibid., xvi.}

30 The History of the Blessed Virgin Mary and the History of the Likeness of Christ, 2 vols. (London: Luzac \& Co., 1899), vol. 2, 71-82 (IGT material in English), vol 1, 67-76 (in Syriac). Budge also reprinted the Syriac text of W for comparison (vol. 1, 217-22).

31 The whereabouts of this Ms, commissioned by Budge himself, is unknown. Émil de Strycker (La forme la plus ancienne du Protévangile de Jacques, Subsidia Hagiographica 33 [Bruxelles: Société des Bollandistes, 1961], 372; repeated by Simon Claude Mimouni, "Vies de la Vierge. État de la question" [Apocrypha 5 (1994)], 241 n. 133) suspected it might be the same as Notre-Dame de Sémances 98, though this Ms, which also is either lost or destroyed, is dated to 1680 and does not contain the other texts listed in Budge's Ms (two Syriac grammars, one by Elias, Metropolitan of Nisibis and the other by John bar-Zô'bhî). Alain Desreumaux ("Les apocryphes syriaques sur Jésus et sa famille," in Les apocryphes syriaques, Études syriaques 2, ed. M. Debie, A. Desreumaux, C. Jullien, and F. Jullien [Paris: Geuthner, 2005], 56) suggests Notre-Dame de Sémances 97, dated to 1689/1690 and apparently unavailable to scholars; however, this Ms also lacks the two grammars. For more on these Mss see further below. 
include the stories. Along with Prot. Jas. and Assum. Vir. the text features the childhood tales set in Egypt found also in Arab. Gos. Inf. It is quite likely, therefore, that the East Syriac Life of Mary is Arab. Gos. Inf.'s long-suspected Syriac source.

The East Syriac Life of Mary has been little studied since Budge's initial work on the text. Certainly it is important for the transmission of the Syriac IGT, but detailed discussion of its contents and its precise relationship to other Syriac IGT recensions is beyond the scope of the present study. However, it is important to clarify for future investigation the available sources for the text. In his 1994 survey of Life of Mary traditions, Simon Claude Mimouni presents lists of unpublished manuscripts of both the East and West Syriac Mary compilations. ${ }^{32}$ The lists contain a number of errors, with some Mss described incorrectly and some placed in the wrong categories. As it turns out, the following Mss are of the eastern form (those marked with $*$ were not known to Mimouni; those marked with $\dagger$ have yet to be evaluated because they are lost or merely unavailable for study):

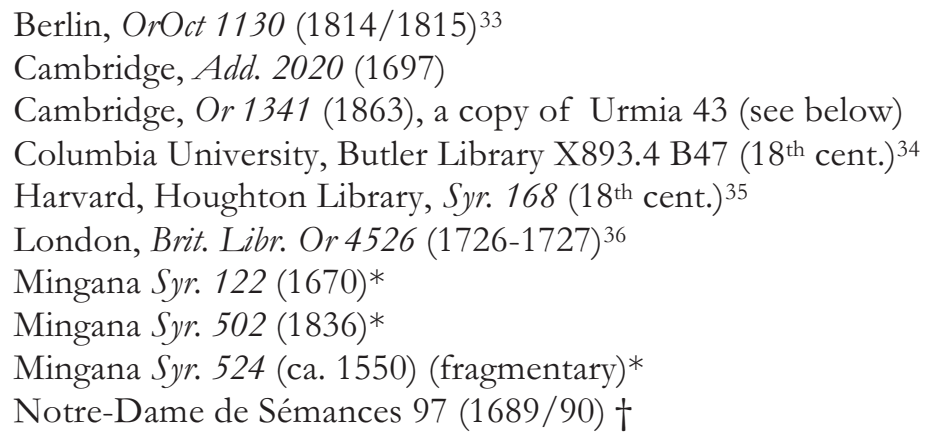

32 Mimouni, "Vies de la Vierge," 239-42. Several of the Mss from Mimouni's lists were mentioned earlier by Anton Baumstark in Geschichte der syrischen Literatur mit Ausscbluss der christlich-palästinensischen Texte (Bonn: A. Marcus \& E. Webers Verlag, 1922), 69-70 n. 12, 70 n. 1, 99 n. 4. Baumstark was uncertain also about the precise contents of the unpublished Mss.

${ }^{33}$ Mimouni and Geerard (CANT) identify this Ms as "Jacobite," i.e., West Syriac.

${ }^{34}$ Mimouni identifies this Ms as West Syriac.

${ }^{35}$ Mimouni identifies this Ms as West Syriac.

${ }^{36}$ Mimouni and Geerard (CANT) identify this Ms as West Syriac. 
Notre-Dame de Sémances 98 (1680) †

Séert 82 (16 ${ }^{\text {th }}$ cent.) $\dagger$

Teheran, Issayi 18 (1741/42 based on a model from $1243 / 1244)^{37}$

Union Theological Seminary, Syr. 32 (18 ${ }^{\text {th }}$ cent.)*

Urmia 38 (1885) †

Urmia 43 (1813), now housed at Princeton's Speer Library $($ Clemons 346) 38

Urmia 47 (1885) †

Vatican, Syr. 587 (1917)*

Vatican, Syr. 597 (17th cent.)*

The East Syriac IGT has several identifying features. It elimates several chapters and there are some transpositions in the order of the material. Essentially, its contents, as found in the more expansive Ms Mingana Syr. 122, are as follows: 6:1, 2f; 4:1-2; 5:1-2; $6: 1-2 c ; 14: 1-3 ; 15: 1-4 ; 16: 1-2 ; 19: 1-2 ; 6: 3-4 ; 7: 1-2 ; 6: 2 \mathrm{e} ; 7: 3-4 ; 6: 2 \mathrm{e}$ (continued); 11:1-2; 13:1-2; 12:1-2.39

\section{Recension Sw}

The West Syriac Life of Mary (=CANT 95) is a complex of biographical material that includes Prot. Jas., the Vision of Theophilus, IGT, and Assum. Vir., divided into six separate books-IGT is here entitled "The fourth book concerning the childhood and upbringing of our Lord Jesus Christ." In 1929, Alphonse Mingana knew of four Mss of this compilation (Mingana Syr. 5, 48, 39, and

37 For a full description see Alain Desreumaux, "Un manuscrit syriaque de Téhéran contenant des apocryphes" (Apocrypha 5 [1994]), 13764.

38 Mimouni lists Urmia 43 as East Syriac but the Princeton Ms as West Syriac. Baumstark mentions Urmia 43 twice in his book, both under IGT (Geschichte der syrischen Literatur, 69-70 n. 12) and under Budge's Life of Mary (ibid., 70 n. 1), but in the latter case he says "eine Verbindung nur mit dem Thomasevangelium liegt vielleicht in Urm 43 vor." A. E. Goodman, "The Jenks Collection of Syriac Manuscripts in the University Library, Cambridge" (JRAS [1939]), 598-99 describes the Ms and says it is of the same recension as the Budge text; this identification is confirmed by my own investigation.

39 Budge's Alqoš Ms and the third of the Se Mss, Mingana Syr. 502, lack $4: 2 ; 5: 1-2 ; 6: 1-2$; and 19:1-2. 
114, the latter two in Garshûni). ${ }^{40}$ Unfortunately, Mingana chose to publish only the Vision material and few scholars have returned to the collection to examine it in more detail. Simon Mimouni, again, listed all of the Mss known to him, though with some infelicities. Charles Naffah corrected some of these in his detailed discussion of the available sources and attempted also to trace a transmission history of all the Life of Mary materials (Sa, Se, and Sw). ${ }^{41}$ My own investigations have supplemented and clarified Mimouni's and Naffah's work, resulting in the following list of West Syriac Life of Mary Mss (again, those marked with * were not known to Mimouni; those marked with $\dagger$ have yet to be evaluated because they are lost or merely unavailable for study):

Cambridge, Add. 2001 (1481)

Charfet, Fonds Rabmani $42(1495) * \dagger$

Charfet, Fonds Rahmani 60 (19 th cent.) (book five only) $* \dagger$

Diyarbakir 99 (between 1728 and 1731) $\dagger^{42}$

Harvard, Houghton Library, Syr. 35 (16/17th cent.)

40 "The Vision of Theophilus, Or the Book of the Flight of the Holy Family into Egypt" (BJRL 13 [1929]), 383-474; reprinted in id., Woodbroke Studies fascicle 5 (Cambridge: W. Heffer \& Sons, 1931). Complete details of the Mss are provided in id., Catalogue of the Mingana Collection of Manuscripts, vol. 1 (Cambridge: W. Heffer \& Sons, Ltd., 1933). Mingana discovered another Ms of the text in his collection (no. 560) subsequent to the publication of his article. Prior to Mingana's edition the work had been made known by way of a summary presentation in François Nau, "La version syriaque de la vision de Théophile sur le séjour de la Vierge en Egypte" (ROC 15 [1910]), 125-32. The Vision of Theophilus also exists as an independent text. See CANT 56 and Clavis Patrum Graecorum 2628 for references to various versions. See also Simon Claude Mimouni, "Genèse et évolution des traditions anciennes sur le sort final de Marie. Étude de la tradition littéraire copte" (Marianum 42 [1991]), 126-29, and the discussion in Stephen Gero, "Apocryphal Gospels. A Survey of Textual and Literary Problems," in $A N R W$ II.25.2, ed. H. Temporini and W. Haase (New York: De Gruyter, 1988), 3983-84.

${ }^{41}$ Charles Naffah, 'Les 'histoires' syriaques de la Vierge: traditions apocryphes anciennes et récentes" (Apocrypha 20 [2009]), 137-88.

42 Mimouni lists this Ms as East Syriac, but the catalogue (Addai Scher, "Notice sur les manuscrits syriaques et arabes conservés à l'archêveché chaldéen de Diarbékir" [JA 10 ${ }^{\text {th }}$ series 10 (1907)], 402-3) identifies the script as West Syriac. 
Harvard, Houghton Library, Syr. 36 (16/17th cent.) (contains only books five and six)

Harvard, Houghton Library, Syr. 39 (1857)

Harvard, Houghton Library, Syr. 59 (1857)*

Harvard, Houghton Library, Syr. $82\left(17 / 18^{\text {th }}\right.$ cent.)

Harvard, Houghton Library, Syr. 129 (17th cent.)*

Mardin 80 (1728-1731) $\dagger^{43}$

Mardin, Dayr Al-Zafaran 393 (20 th cent.)

Mingana Syr. 5 (1479) ${ }^{44}$

Mingana Syr. 48 (1906, but copied in part from a manuscript of 1757)

Mingana Syr. 184 (1637)* (contains only the end of book six)

Mingana Syr. 560 (1491)*

Paris, Bib. nat. 377 (1854/1855)*

Vatican, Borgia Syr. 128 (1720) (does not contain book four)

Vatican, Syr. 537 (16 th cent.)*

And four Garshûni Mss: Charfet, Fonds Rabmani 48 (15/16 th cent.) * +, Mingana Syr. 39 (from 1773), the more recent Syr. 114, and Vatican, Syr. 561 (1683; fragmentary).*

The $\mathrm{Sw}$ recension is characterized by a number of omissions. All Mss examined thus far lack ch. 2:5; end prematurely in $6: 2 \mathrm{~d}$; lack "for thus was his name" in 9:3, sections of 11:2, 13:1, 13:2, and 16:1 (the latter four are found in Mingana Syr. 48; their presence in this Ms alone suggests some corruption between Syr. 48 and the branch behind $\mathrm{P}$ and $\mathrm{M}$ ); a sentence is missing in 19:1, and part of a sentence in 19:2 (the latter preserved only in three Mss, perhaps again due to corruption). The tradition also features a number of unique readings, the more prominent of which are: the son of Hannān the scribe disturbs Jesus' pools "when he saw his mercy" (3:1); those cursed in 5:1 shall not see "life" rather than "their torment"; "Levite" replaces "Pharisee" in the list of offices in 6:2c; the raised Zeno defends the wrongly-accused Jesus by saying, "rather so-and-so threw me down" (9:3); and Jesus' cloak in 11:2 is

${ }^{43}$ Again, Mimouni lists this Ms as East Syriac, but the catalogue (Addai Scher, "Notice sur les manuscripts syriaques et arabes conservés dans la bibliothèque de l'évêché chaldéen de Mardin" [Revue des Bibliothèques 18 (1908)], 86) identifies the script as West Syriac.

${ }^{44}$ Mimouni erroneously gives a date of 1790 (1479=" 1790 of the Greeks"). Geerard (CANT p. 73) makes the same error. 
identified as "his sticharion" (the liturgical vestments in eastern churches). Some readings in $\mathrm{Sw}$ result from error: for example, "teach him to bless" (4:2) is rendered "teach him to be humble," the verb for "I shall lay aside" (6:2b) is misspelled, and the restoration of those whom Jesus cursed ("And those who had fallen under the curse lived and rose up") in 8:2 becomes a command by Jesus ("“And let those who had fallen under the curse rise"').

\section{Additional Sources for the Syriac IGT}

Mention should be made also of two Arabic translations related to the Syriac tradition. The first is Arab. Gos. Inf. (CANT 58; BHO 619). This gospel has been known since its publication by Henry Sike in 1697.45 For his edition, Sike used a Ms now held at the Bodleian Library (Oxon. Bodl. Or. 350).46 This is the only version of the text so far to have been translated into English, though quite some time ago. ${ }^{47}$ Even Peeters' French translation follows Sike's Ms, as he was unable to obtain a copy of Vat. Syr. 159 before his translation went to press. ${ }^{48}$ A third Ms (Florence, Biblioteca Laurenziana, codex orientalis 387 [32]; dated to 1299) was examined and translated into Italian by Mario E. Provera in $1973 .{ }^{49}$

45 Henry Sike, Evangelium Infantiae; vel, Liber Apocryphus de Infantia Salvatoris; ex manuscripto edidit, ac Latina versione et notis illustravit Henricus Sike (Utrecht: Halman, 1697).

${ }^{46}$ Charles Genequand, "Vie de Jésus en Arabe," in Écrits Aporryphes Chrétiens, vol. 1, ed. François Bovon and Pierre Geoltrain (Paris: Gallimard, 1997), 209.

47 Alexander Walker, Apocryphal Gospels, Acts and Revelations (Edinburgh: T. \& T. Clark, 1870) (=The Ante-Nicene Christian Library, vol. 16, ed. Alexander Roberts and James Donaldson. Vol. 16), 100-24; and Benjamin Harris Cowper, The Apocryphal Gospels and Other Documents Relating to the History of Christ, $4^{\text {th }}$ ed., 1867 (reprint: London: Frederic Norgate, 1874), 170-216. Both translations were made from the Latin translation of Sike's text in Tishendorf, Evangelia Apocrypha, 181-209.

48 Peeters, Évangiles Apocryphes, lvi.

${ }^{49}$ Il V angelo arabo dellinfanzia secondo il Ms. Laurenziano orientale (n. 387) (Jerusalem: Franciscan Printing Press, 1973). See also the discussion and French translation of the new Ms by Genequand ("Vie de Jésus en Arabe," 201-38). A number of other manuscripts are known, but these have not been edited or evaluated. See George Graf, Geschichte der christlichen Arabischen Literatur, vol. 1 (Vatican City: Biblioteca Apostolica 
According to Charles Genequand, the three published Arab. Gos. Inf. Mss represent three independent translations of the East Syriac Life of Mary: the Florence manuscript, which follows the Syriac text most closely but does not include IGT, Peeters' Ms with IGT appended, and Sike's Ms with a different version of IGT (it has additional chapters and differences in sequence) fully incorporated into the text. ${ }^{50}$ The three East Syriac Life of Mary Mss that include the IGT stories seem to reflect another independent effort to combine the tales with the Marian apocrypha.

The second Arabic text is a separate translation of IGT alone. Sergio Noja presented an edition of the text from a Ms from Milan (Biblioteca Ambrosiana, G 11 sup), first in a French translation in 1990, then in an edition of the Arabic original in 1991.51 In form it follows the shorter recension of the early versions, but lacks sections from chapters 6 and 7 and the entire chapters 12, 15 and 19. It also includes two additional stories: Jesus and the Dyer and a tale similar to Jesus Turns Children into Swine (both of which are found in the East Syriac Life of Mary and Arab. Gos. Inf. as well as other infancy story collections).

\section{THE RELATIONSHIP BETWEEN THE RECENSIONS}

It is undeniable that $\mathrm{P}$ (along with $\mathrm{M}$ ) represents, now, the best source published thus far for the Syriac tradition of IGT. It contains the chapters and parts of chapters missing in $\mathrm{W}$ and $\mathrm{G}$, and, as illustrated by the significant agreement between the four Mss, does not appear to have undergone much alteration over the centuries, despite the fact that $\mathrm{W}$ and $\mathrm{G}$ antedate $\mathrm{P}$ and $\mathrm{M}$ by a millennium. Some questions remain, however, about $\mathrm{P}$ and M's relationship to $\mathrm{W}$ and $\mathrm{G}$ and to other branches of the Syriac IGT tradition.

Vaticana, 1944), 225-27 for a description of some unpublished Mss with portions in Syriac and Garshûni.

50 Genequand, "Vie de Jésus en Arabe," 208.

51 "L'Évangile arabe apocryphe de Thomas, de la 'Biblioteca Ambrosiana' de Milan (G 11 sup)," in Biblische und Judistische Studien. Festschrift für Paolo Sacchi, Judentum und Umwelt 29, ed. Angelo Vivian (Paris: Peter Lang, 1990), 681-90; id., “À propos du texte arabe d'un évangile apocryphe de Thomas de la Ambrosiana de Milan," in YADNAMA: im memoria di Alessandro Bausani, vol. 1, ed. Biancamana Scarcia Amoretti and Lucia Rostagno (Rome: Bardi Editore, 1991), 335-41. 
Alain Desreumaux and Charles Naffah have argued that the Syriac IGT never existed as a separate text from the Life of Mary compilations. Naffah's developmental theory holds that the Life of Mary compilation as it stands in the early Mss (W and G) grew to become the six-book West Syriac collection on the one hand and the lengthy East Syriac collection on the other. ${ }^{52}$ Desreumaux has spoken out in support of Naffah's position. He argues that the compiling of texts observable in $G$ and $W$, as well as in a fragmentary palimpsest edited by Agnes Smith Lewis (the latter featuring only Prot.Jas. and Assum. Vir.), 53 indicates that, "en syriaque ces différent épisodes n'existent jamais à l'état séparé, mais sont toujours des chapitres d'une Histoire suivie de la Vierge, de sa naissance à sa mort." ${ }^{54}$ However, $\mathrm{P}$ and $\mathrm{M}$ - the former with IGT appended to Arab. Gos. Inf., the latter featuring IGT alone-cast doubt on such a theory. Desreumaux accounts for these Mss as texts that have "broken off" from the Life of Mary tradition. But there is reason to believe that $\mathrm{P}$ and $\mathrm{M}$ are evidence for Syriac IGT circulating independently as a distinct text up until the nineteenth century.

First, $\mathrm{P}$ and $\mathrm{M}$ cannot be excerpts from the two later compilations. The West Syriac Life of Mary collection features Prot. Jas., IGT, the Vision of Theophilus, and Assum. Vir. divided into roughly six books (some Mss divide Assum. Vir. into "book six" and an epilogue). Each of the texts has its own title and a number-IGT, for example, is named "book four." Two of the witnesses for the West Syriac Life of Mary feature only IGT: Houghton Library, Syr. 59 and the closely-related Paris, Bib. nat. 377. But these two have indeed "broken off" from the Life of Mary tradition as their titles retain the identification of the text as "book four" of a collection and they share the omissions and unique readings characteristic of the $\mathrm{Sw}$ recension (noted above). $\mathrm{Sw}$ also lacks most of $\mathrm{P}$ and M's idiosyncratic readings (including the much-expanded ch. 9, and the readings listed in the appendix under "Significant readings shared by $\mathrm{P}$ and $\mathrm{M}$ " and "Corruptions in $\mathrm{P}$

${ }^{52}$ Naffah, "Les 'histoires' syriaques de la Vierge," 140-59.

53 Apocrypha Syriaca. The Protevangelium Jacobi and Transitus Mariae with Texts from the Septuagint, the Coran, the Peshitta, and from a Syriac Hymn in a Syro-Arabic Palimpsest of the fifth and other centuries (Studia Sinaitica No. XI) (London: C. J. Clay, 1902).

${ }^{54}$ Desreumaux, "Deux anciens manuscrits syriaques," 119. 
and M"), and it contains many of the readings from $W$ and $G$ lacking in $\mathrm{P}$ and $\mathrm{M}$ (see "Significant readings in $\mathrm{W}$ and $\mathrm{G}$ absent in $\mathrm{P}$ and $\mathrm{M}$ "). There is significant agreement also in those readings from $\mathrm{P}$ and $\mathrm{M}$ that may be more original than their parallels in $\mathrm{W}$ and $G$, indicating that $\mathrm{Sw}$ can be helpful in adjudicating between readings in the $\mathrm{Sa}$ recension.

As for the East Syriac Life of Mary, the evidence suggests that IGT was added late to that compilation. The best witness to Arab. Gos. Inf. (Provera's Florence Ms) is a translation of a version of the East Syriac Life of Mary that did not contain IGT; and the majority of the East Syriac Life of Mary Mss also lack IGT, suggesting that its presence in the three remaining Mss may be a later addition to the tradition. In addition, the form of IGT included in Sike's Arab. Gos. Inf. is much different from that found in Se; so too is the Arabic IGT.

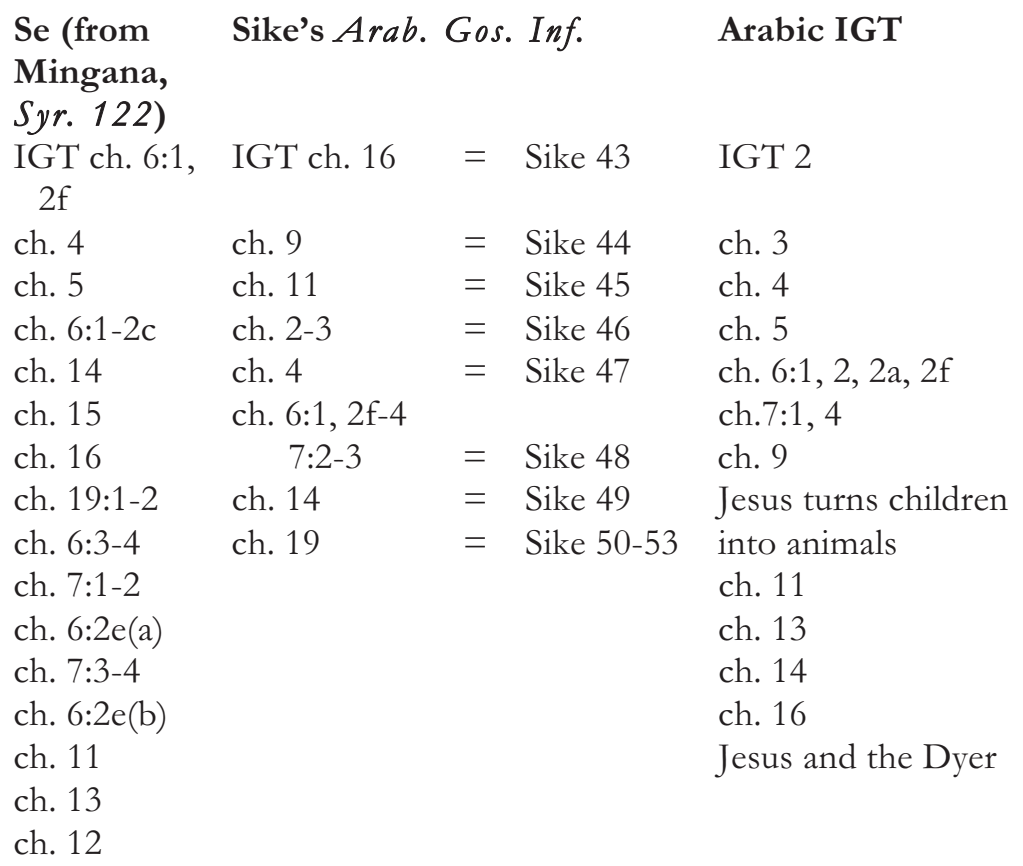

Clearly, P and M cannot have "broken off" from the East Syriac Life of Mary nor from its West Syriac counterpart. Nor could they have developed out of the branch of the tradition found in W and $G$, for these two Mss lack many sections of the text found in $P$ 
and M. The two Mss could only have become detached from the Syriac Life of Mary tradition if they derive from a branch distinct from any of the witnesses that are currently extant. The evidence instead shows that there have been a number of independent attempts to join the Syriac IGT to Marian apocrypha. The SmithLewis palimpsest features only Prot. Jas. and Assum. Vir. To this collection was added IGT to give us W and G. In the East Syriac milieu new stories of the infant Jesus were combined with Prot. Jas. and Assum. Vir. to form the East Syriac Life of Mary; at a later stage IGT was added to create the three Se Mss, while elsewhere a number of chapters from IGT were translated into Arabic and added to Arab. Gos. Inf. to form Sike's Ms. In the West Syriac milieu Prot. Jas., the Vision of Theophilus, IGT, and Assum. Vir. were combined to form the West Syriac Life of Mary. Throughout all of this activity, IGT circulated independently, drawn upon by all of the participants and available in the seventeenth and nineteenth centuries in two Mss: P and M. Despite the differences between the various forms of Syriac IGT, the commonalities in language indicate that they are all witnesses to a single translation of the text from Greek made in or prior to the fifth century.

\section{A SYRIAC ORIGIN FOR IGT?}

The introduction to Peeters' volume of infancy gospels details his theory of Syro-Arabian origin for the various infancy gospel traditions-namely, Arab. Gos. Inf., Arm. Gos. Inf., and IGT. According to the theory, all of the childhood stories found in these texts derive from a larger collection of legends assembled in Syriac in the fifth century. The IGT material, he claimed, became detached from the collection and was then translated into Greek to form $\mathrm{Ga}$ and $\mathrm{Gb}$ (the only Greek forms known to Peeters at the time), and into Latin to form LV, LM, and LT. Unfortunately, Peeters did not offer any proof for his assertion of Syriac composition for IGT; he declared only that an inverse relationship from Greek to Syriac would not work. ${ }^{55} \mathrm{He}$ did, however, draw attention to variant readings from one particular Ms of the Gospel of Pseudo-Matthew (Paris, Bibl. nat., lat. 1652; =Tischendorf's D Ms) which he attributes to mistranslations from Syriac. But, even if found sufficiently compelling, these readings are at best proof of

${ }^{55}$ Évangiles apocryphes, xvii-xx. 
transmission of Ps.-Matt.'s IGT material from Syriac to Latin, but not Syriac composition of IGT.

Peeters was not the first scholar to argue that IGT was composed in Syriac. Even before the publication of the first Syriac Ms, Michel Nicolas argued for Syrian origin of the text. His Études sur les évangiles apocryphes outlines Nicolas' belief that all the infancy gospels were written by Syrian Jewish-Christians. ${ }^{56}$ As proof he cited IGT's attribution to Thomas ${ }^{57}$ and the low quality of its Greek which, he claimed, owes itself to slavish translation from Syriac. ${ }^{58}$ In 1867 Benjamin Harris Cowper included a translation of Wright's recently published $\mathrm{Ms}$ (W) as an appendix in his Apocryphal Gospels collection. ${ }^{59}$ Cowper believed the Syriac tradition to be important due to its antiquity and its agreements with LV. He suggested, as a result, that IGT may have been composed in Syriac. ${ }^{60}$ A Syrian origin was postulated next by Jean Variot in his comprehensive 1878 study Les évangiles apocryphes. ${ }^{61}$ Using the evidence from W, Variot built on Nicolas' theory, adding his opinion that $\mathrm{W}$ demonstrates signs of an earlier tradition-it has fewer errors than the Greek and shows a concern for the law (see ch. $6: 2 \mathrm{~b}$ below). ${ }^{62}$

Peeters' contribution to this argument attracted criticism from subsequent scholars. In an early review of Peeters' volume, Montague Rhodes James wrote, "I do not see that he dismisses the idea that the parent of all the extant texts of Thomas was in Greek. This must be regarded as practically certain, in view of knowledge of it shewn by Hippolytus and perhaps by Irenaeus." 63 Aurelio de Santos Otero credited Peeters' lack of confidence in a Greek $290-4$.

56 Études sur les évangiles apocryphes (Paris: Michel Lévy Frères, 1866),

${ }^{57}$ Nicolas, Études, 199.

${ }^{58}$ Ibid., 331.

59 The Apocryphal Gospels and Other Documents Relating to the History of Christ, 4th ed., 1867 (reprint: London: Frederic Norgate, 1874), 448-56.

${ }^{60}$ Ibid., 128, cf. lxxii.

${ }^{61}$ Les évangiles apocryphes: Histoire littéraire, forme primitive, transformations (Paris: Berche \& Tralin, 1878).

${ }^{62}$ Ibid., 46-7.

63 Review of Évangiles apocryphes, vol. 2, by Paul Peeters (JTS 16 [1915]), 269. Though note that it is now believed Hippolytus was referring to the Gospel of Thomas, not IGT. 
original to the state of the available Greek Mss, though de Santos failed to provide convincing examples of readings in the Syriac Mss resulting from corruption of a Greek Vorlage. ${ }^{64}$ Stephen Gero objected to Peeters' refusal to offer evidence for his theory, ${ }^{65}$ and Oscar Cullman merely called Peeters' theory "untenable."66 While the majority of scholars still believe IGT's language of origin to be Greek, Peeters' Syro-Arabian theory was entertained by French scholars for some time, ${ }^{67}$ and a Syriac original has been mentioned at least as a possibility by English, American, and German scholars. ${ }^{68}$

More direct challenges to Peeters' Syriac-composition theory have been offered by Sever Voicu and in my work on the text. In his expansive 1998 study of IGT, ${ }^{69}$ Voicu lists three indications in the text of Greek, not Syriac, composition ${ }^{70}$ : 1. the letter speculation section in ch. 6:4 features a number of neologisms which may be formed naturally in Greek but not in Semitic

${ }^{64}$ Das kirchenslavische, 148-51.

65 "The Infancy Gospel of Thomas," 48 n. 1.

66 "The Infancy Story of Thomas," in New Testament Apocrypha, vol. 1: Gospels and Related Writings, rev. ed., ed. Wilhelm Schneemelcher, trans. R. McL. Wilson (Louisville, Ky.: Westminster John Knox, 1991), 439.

${ }^{67}$ See Émile Amann, "Apocryphes du Nouveau Testament," in DBSup vol. 1 (Paris: Librairie Letouzey \& Ané, 1928), 485-6; Pierre Saintyves, "De la nature des évangiles apocryphes et de leur valeur hagiographique" (RHR 106 [1932]), 436; Christian Bigaré, "L'achèvement des Ecritures," in Introduction à la Bible, vol. 5, eds. Pierre Grelot and Christian Bigaré (Tournai: Desclée, 1977), 195. Also, Charles H. Henkey, "Bible, Apocrypha of the New Testament," in New Catholic Encyclopedia, vol. 2 (New York: McGraw-Hill, 1967), 405 mentions Peeters' work as a counter theory to second-century composition.

${ }^{68}$ See James Keith Elliott, The Apocryphal New Testament. A Collection of Apocryphal Christian Literature in an English Translation (Oxford: Clarendon Press, 1993), 69; Gerhard Schneider, Apokryphe Kindheitsevangelien (New York: Herder, 1995), 38-39; Montague Rhodes James, "The Gospel of Thomas" (JTS 30 [1928]), 51-4. Despite his earlier assessment of the theory of Syriac composition, James hoped the recovery of additional lines from LV would determine whether or not Peeters was correct. Additional lines have since been deciphered but they have made no impact on the discussion.

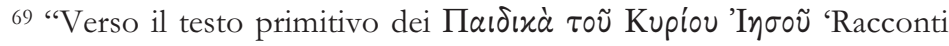
dell'infanzia del Signore Gesù"' (Apocrypha 9 [1998]), 7-95.

${ }^{70}$ Ibid., 53-55. 
languages like Syriac; 2. the use of the Semitic letters aleph and beth (rather than alpha and beta) in the Teacher episodes (chs. 6 and 14) is a common variant shared by the Syriac and early Latin traditions ${ }^{71}$; and 3. the Greek title of the text uses the term $\pi \alpha \iota \delta$. $\alpha$, a word unique to Greek and difficult to translate-the versions, including the Syriac, variously simplify the term as "childhood." Despite Voicu's efforts, only the first of his points is truly an argument for Greek composition. The question of language of origin was addressed in more detail in my 2010 critical edition of the Greek IGT tradition. ${ }^{72}$ Drawing upon studies on how to determine if a Greek text is translated from a Semitic original, ${ }^{73} \mathrm{I}$ illustrated that Gs, the earliest of the Greek recensions, meets virtually all the criteria for composition in Greek. ${ }^{74} \mathrm{I}$ also examined IGT's use of Luke 2:41-52 (reproduced and expanded in IGT 19). ${ }^{75}$ If composed in Syriac, this chapter should show significant verbatim agreement with Old Syriac Luke; in fact, I demonstrated that such verbatim agreement is minimal in Syriac, but it is observable between Gs and Greek Mss of Luke. Syriac word order is much less flexible than Greek, so some agreement between Syriac IGT and Old Syriac Luke is inevitable, but the presence of synonyms-such as, فهת (IGT) vs. v (SyrLuke) for "remained/tarried" (v. 43) and مisxds (IGT) vs. مemesh (SyrLuke) for "astonished" (v. 47)—suggests that the creator of Syriac IGT is not incorporating Old Syriac Luke 2 into his text, as

${ }^{71}$ Neither the Ethiopic nor the Georgian texts contain this variation nor do the second-century witnesses to the story: Epistula Apostolorum 4 and Irenaeus, Haer. 1.20.1. Voicu attributed the presence of the Hebrew letters to a revision made for the sake of verisimilitude. A similar, and apparently independent, alteration is found in the Greek P Ms and LT ("A usque ad T") and is implicit in Gb's description of a 22-letter alphabet.

72 Burke, De infantia Iesu euangelium, 174-88, a revision of ChartrandBurke, "The Infancy Gospel of Thomas, 247-54.

${ }^{73}$ Primarily Raymond A. Martin, Syntactical Evidence of Semitic Sources in Greek Documents, Septuagint and Cognate Studies 3 (Cambridge, Mass: Society of Biblical Literature, 1974), and also Nigel Turner, Grammatical Insights into the New Testament (Edinburgh: T. \& T. Clark, 1965), and John Merle Rife, "The Mechanics of Translation Greek" (JBL 52 [1933]), 24552.

${ }^{74}$ Burke, De infantia Iesu enangelium, 178-82.

${ }^{75}$ Ibid., 182-88. 
one would expect, but performing his own translation of a Greek version of IGT.

Now that the full text of Peeter's Ms is available, it is worthwhile to re-visit Peeters' theory of Syriac composition. Alas for Peeters, the full publication of $\mathrm{P}$ presents no compelling reason to doubt that IGT was composed in Greek. In my initial work on this issue, the data were drawn only from those sections of Gs that had parallels in the Syriac tradition available at the time-i.e., the verses for which there were no parallel in $\mathrm{Ms} \mathrm{W}$ were not included in the analysis. The publication of $\mathrm{P}$ offers a more complete version of the text (i.e., the addition of all of chs. 6-8, 14, and 15); but, the inclusion of the new material would change the outcome of the investigation only in minor, statistically-insignificant ways. However, more depth can be added to the comparison of Syriac IGT 19 with Old Syriac Luke 2:41-52. Included for comparison also are readings from the Diatessaron, which should be considered a possible source for the Syriac IGT. Unfortunately, very little of the Diatessaron's story of Jesus in the Temple is extant in Syriac. Ephrem's Commentary on the Gospel of the Mixed, preserved in Syriac and Armenian, ${ }^{76}$ includes only portions of Luke 2:48 (in 2,7 and 3,16), $49(3,16)$, and $51(5,2)$. Other sources for the Diatessaron exist, but only the Arabic and Persian are likely to be syntactically close to the Syriac and even these translations are believed to have been vulgatized. Complicating the issue also is the fact that Old Syriac Luke contains Diatessaronic readings. ${ }^{77}$ Unless and until a complete Syriac edition of the Diatessaron is discovered, it is impossible to determine whether or not the Syriac IGT could have used the harmony. For now we must rely on the readings available to us in Syriac.

First, several readings in $\mathrm{P}$ (and sometimes $\mathrm{M}$ ) absent in $\mathrm{W}$ have parallels in Old Syriac Luke: مله

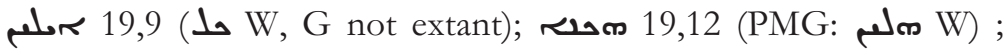
19,21 (om. W; G

${ }^{76}$ For the Syriac text see Louis Leloir, Saint Éphrem, Commentaire de l'Évangile concordant, texte syriaque (Manuscrit Chester Beatty 709). Folios Additionnels, CBM 8(b) (Leuven: Peeters, 1990).

${ }^{77}$ For details on the interrelationships of the Diatessaron witnesses see William L. Petersen, Tatian's Diatessaron: Its Creation, Dissemination, Significance, and History in Scholarship, VGSup 25 (Leiden et al.: E. J. Brill, 1994). 


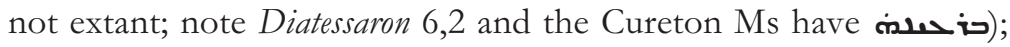

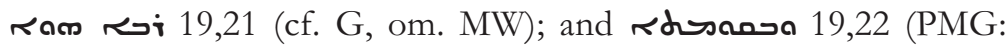
om. W). Particularly significant is P's rendering of $\lambda u \pi 0^{\prime} \mu \varepsilon v o r$ (19:3), a reading shared between Gs and Codex Bezae along with other Western witnesses, including Old Syriac Luke. The other Syriac

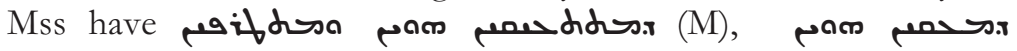
مد (WG) ("we were distressed and anxious"), but Ms P reflects, again, the reading in Old Syriac Luke rrev ("in great agitation," 19,13) and the Diatessaron $(2,7$; but 3,16 has only riat). In sum, the wider Ms base for Syriac IGT shows more commonalities with Old Syriac Luke than my earlier study of Ms W alone.

Secondly, comparison between the IGT Mss and the various forms of Syriac Luke show that agreements can be found not only with the Old Syriac text but at times with the Peshitta and/or the Harklean version against the Old Syriac, particularly in sentence structure. See, for example, Luke 2:43 (noting the similarities between $\mathrm{W}, \mathrm{G}$, and Harklean Luke):

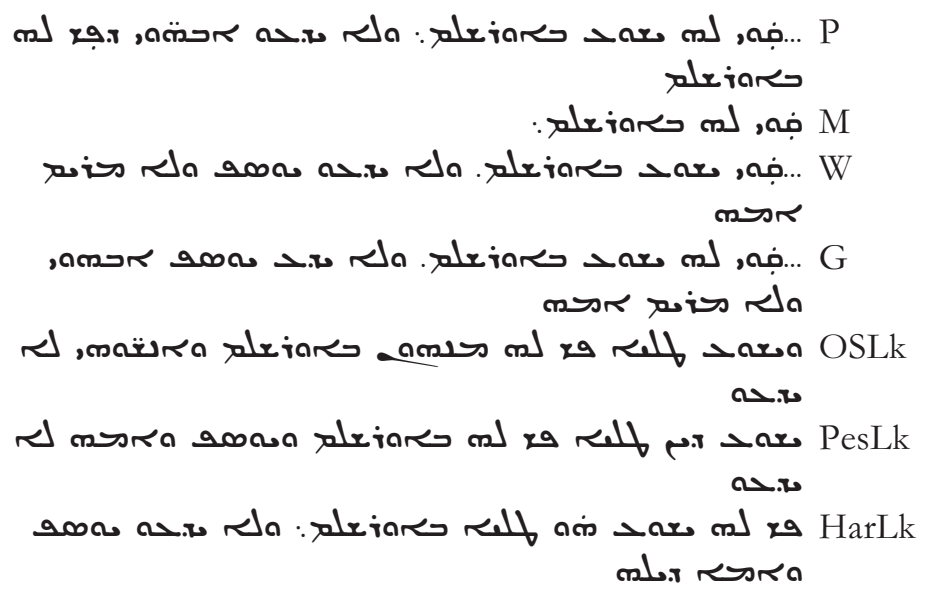

Finally, despite $\mathrm{P}$ and M's greater agreements with the Syriac versions of Luke, there remain still a number of readings unique to the IGT Mss:

19,4 فم 19 ("remained"; IGT, though note P ) vs. ("tarried"; SyrLuke v. 43) 


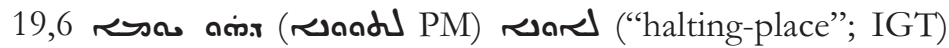

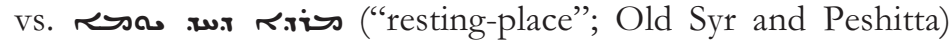
and rso.x Ruiar ("journey"; Harklean)

19,6-7 لdal ("among their kinsfolk"; IGT and Harklean!) vs. amdiarer dado amdual sul ("among the people of their company and among their relatives"; Old Syr) and amdicur dal ("among their relatives"; Peshitta)

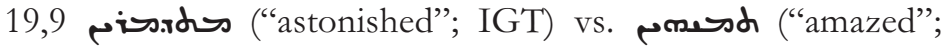

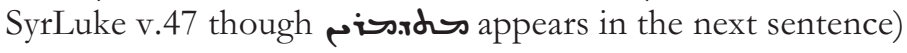

19,15 ramsl (IGT) vs. ramr.x (SyrLuke v. 49; Diatessaron $3,16)$ both variants of "to be"

19,21 the element idudso is common to all four Mss but lacking in all versions of SyrLuke v. 52

The evidence indicates that Syriac IGT does not directly incorporate Syriac Luke in any known form. There is much variation in the IGT Mss, though it does appear that greater harmonization with Syriac Luke (perhaps in the Peshitta form) occurs in the later Mss ( $\mathrm{P}$ and $\mathrm{M})$. Similar phenomena are observable in the Greek IGT Mss; they too do not agree with any particular family of Greek Luke Mss and show various degrees of harmonization with the canonical text. Nevertheless, the departures from Old Syriac Luke, particularly in the earliest Mss (W and G), suggest that the creator of Syriac IGT is either freely composing his text without a version of Syriac Luke before him (or without a known version of Syriac Luke before him), or he is translating a Greek form of IGT 19 and, by extension, his entire text is a translation from Greek. Nevertheless, the best evidence for IGT's language of composition remains the results obtained from applying the methodology for determining when a Greek text is a translation from a Semitic original. And that methodology indeed indicates that IGT was composed in Greek.

\section{TEXT AND TRANSLATION}

The diplomatic edition of Ms P that follows features an apparatus containing variant readings from $\mathrm{W}$ and $\mathrm{G}$ - the two Ms that most closely resemble $\mathrm{P}$ and that remain our earliest witnesses to the 
tradition-and another unpublished Ms (M) that is very similar to P. Budge's Ms A is not included as it should be examined first in relation to the unpublished Se Mss. Diacritics and vowels are not retained in the edition, nor for other Mss in the apparatus, unless they can affect meaning. The original punctuation also has not been retained, nor have abbreviations. No attempt has been made to emend $\mathrm{P}$ where it appears to be deficient; however, some corrections have been incorporated into the English translation (placed between $<>$ ) where the text is otherwise incoherent, and some words (placed between []) have been added for clarification. These are all acknowledged in the accompanying notes. Suggested emendations, false readings, etc. made by previous editors (Wright, Peeters, and Baars) are provided in the apparatus and notes. Chapter and verse numberings derive from the standard usage for Ga.

\section{Sigla}

\begin{tabular}{|c|c|}
\hline $\mathrm{P}$ & Vatican Syr. 159 \\
\hline M & Mingana Syr. 105 \\
\hline W & London, British Library, Add. 14484 \\
\hline G & Göttingen, Universitätsbibliothek, $S y r .10$ \\
\hline Wright & Edition of W by W. Wright \\
\hline Baars & Collation of $G$ by W. Baars \\
\hline Peeters & Suggested emendations of P by P. Peeters \\
\hline Se & $\begin{array}{l}\text { Readings from IGT in the East Syriac Life of Mary } \\
\text { tradition (offered in the English translation for } \\
\text { comparison) }\end{array}$ \\
\hline Sw & $\begin{array}{l}\text { Readings from IGT in the unpublished West Syriac Life } \\
\text { of Mary tradition (offered in the English translation for } \\
\text { comparison) }\end{array}$ \\
\hline
\end{tabular}

\section{Appendix: Description of the Manuscripts}

P Vatican Syr. 159, paper, $31.1 \times 21.5$ cm., 470 fol., 2 col., 1622/162378: fol. $237^{\mathrm{r}}-239^{\mathrm{v}}{ }^{79}$

78 Baumstark, Geschichte der syrischen Literatur, 69-70 n. 12, following Assemani, dates the Ms to 1628/32. Peeters (Évangiles apocryphes, xiv) reveals that the section of the Ms containing the infancy material (fol. $231^{\mathrm{v}}-239^{\mathrm{v}}$ ) was transcribed in 1622/1623 (see fol. 231 ${ }^{\mathrm{v}}, 275^{\mathrm{v}}$ ). 
As Peeters reports, the IGT material here is found in Syriac appended, without a new title, to a version of Arab. Gos. Inf. in Garshûni. Arab. Gos. Inf. begins on fol. 231 with the title of IGT (in Syriac) but the text of IGT does not begin until fol. 237r. Two scribal notes (fol. 231v, 275v ) pinpoint the composition of this section of the Ms to the convent of Mar Cyriacus or of Abu Galeb, near Gargar. ${ }^{80}$ Two other non-canonical texts are contained in the Ms: Apoc. Paul (fol. 197f.), and the Book of Clement (aka Apocalypse of Peter, aka the Book of the Rolls) (fol. 228f.). The Ms also contains works by Ephrem and the canonical epistles of James and 1 Timothy. The copyist of IGT commonly abbreviates the third person singular possessive and a few other words, and vowels are employed on rare occasions; neither of these phenomena are signaled in the edition. The Ms has two curious marginalia on fol. 238v: حal (from mall?=his wrapping) near ch. 11 (perhaps a reference to Jesus' hood, ria

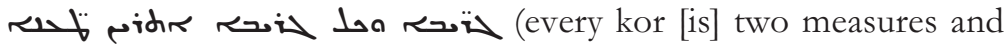
every measure [is] two loads) near ch. 12.

IGT is complete in the Ms; however, there are a few sections that are blacked out: three cases of what appear to be erasures of dittography $(5,6 ; 6,49$ and 9,5), and two lines of text in 7,15-16, the contents of which, fortunately, can be reconstructed from Ms M. There appears to be a case of homoeoteleuton in 19,7-8 and a number of clearly corrupt (signaled in the apparatus by "err.") and idiosyncratic readings:

Deficiencies in $\mathbf{P}$ not present in other Mss (where readings are extant):

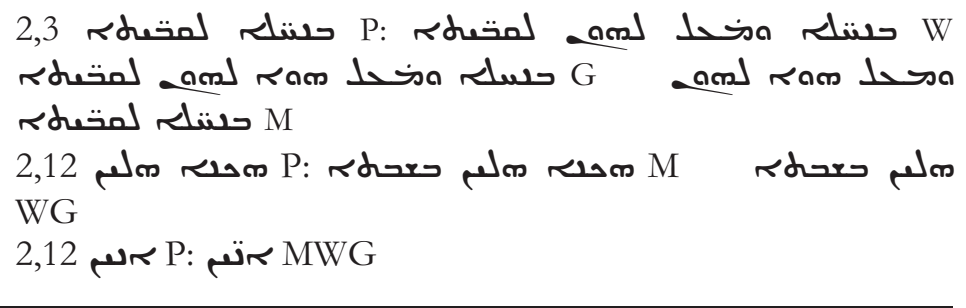

79 Stefano Evodio Assemani, Bibliothecae Apostolicae Vaticanae Codicum Manuscriptorum catalogus, vol. 3, Reliquos Codices Chaldaicos sive Syriacos (Paris: Maisonneuve, 1926), 307-19. The pages originally were numbered 104r-106v .

${ }^{80}$ See Peeters, Évangiles apocryphes, xiv. 


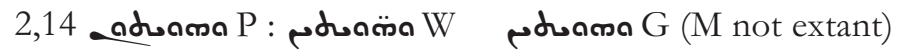

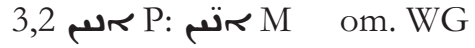

4,3

5,5 post له MW add.

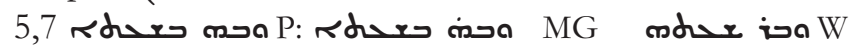

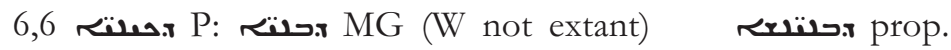

Peeters

6,29 post d

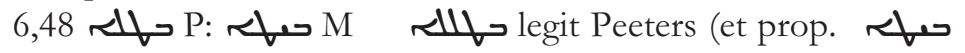
๘) (W and $G$ not extant)

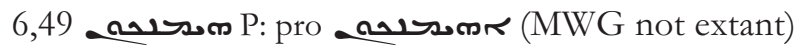

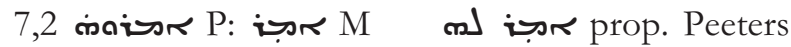

همربن

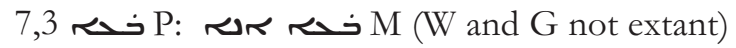

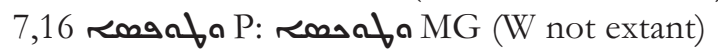

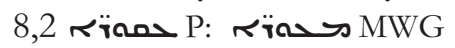

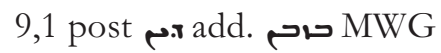

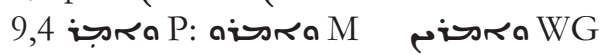

9,5 ram $\mathrm{M}$

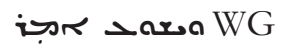

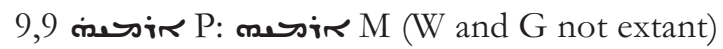

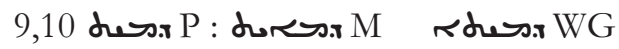

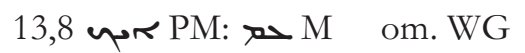

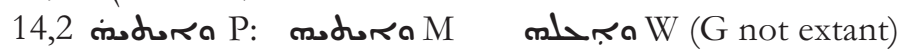

15,5 حلd Pd M (W and G not extant)

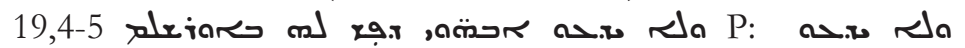

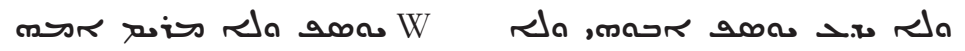

a $G$ (M not extant)

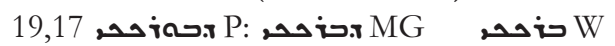

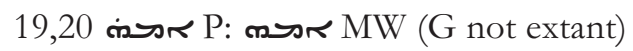

Significant readings unique to $P$ :

4,7 8. O. M. MWG

5,5 P: om. MWG

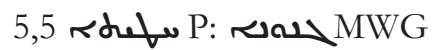

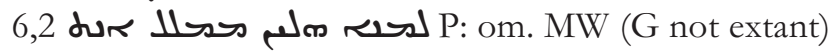

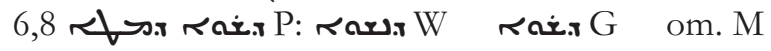




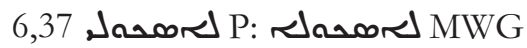

6,52 in (i) P: om. M (W and G not extant)

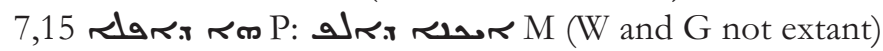

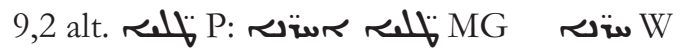

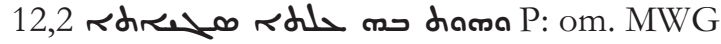

12,3 דבמה P: om. WG (M not extant)

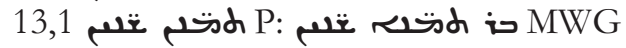

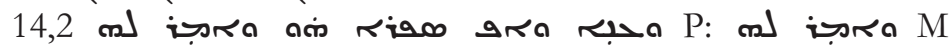

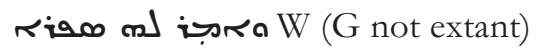

14,3 alt. ₹ P: om. MW (G not extant)

15,10 لم P: om. M (W and G not extant)

16,5 rddasa P: om. MWG

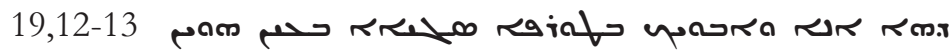

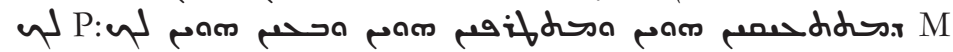

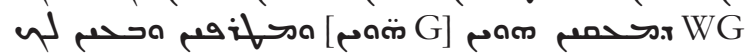

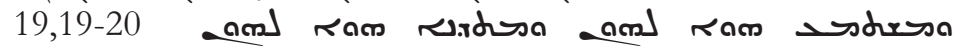

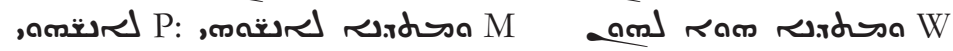

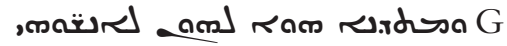

19,21 dom Rasua P: om. MWG

There are also a number of corrupt and significant unique readings shared by $\mathrm{P}$ and $\mathrm{M}$ :

Corruptions in $\mathbf{P}$ and $\mathbf{M}$ :

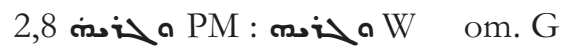

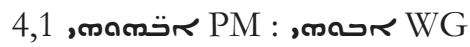

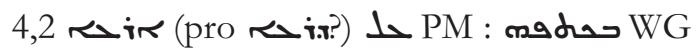

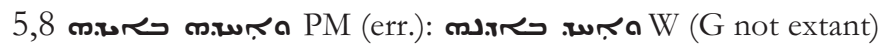

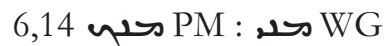

6,18 alt. ه PM : ه :

6,26 $\mathrm{JPM}:$ W (G not extant)

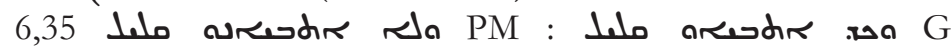

1.

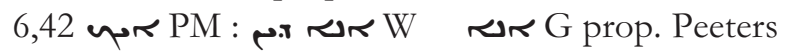

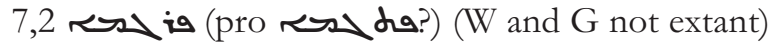

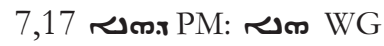

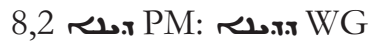

9,3 iudrero (pro iwadrera) PM: undrra G ra WW 
19,6 rradd PM : rard WG

Significant readings shared by $P$ and $M$ :

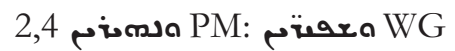

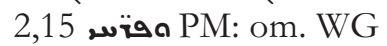

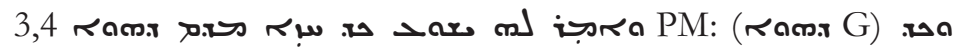

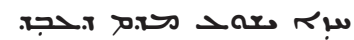

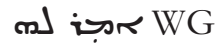

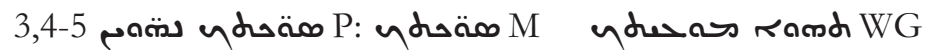

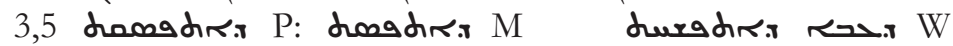
duradira $G$

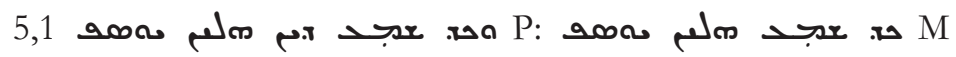
om. WG

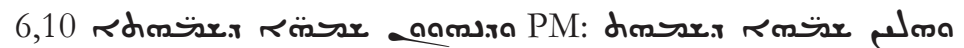

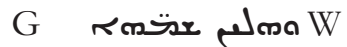

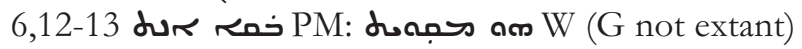

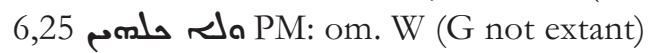

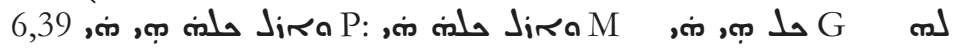
هل $\mathrm{W}$

9,7-13 expanded readings (see the text and translation for details)

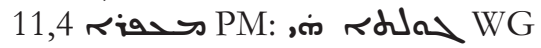

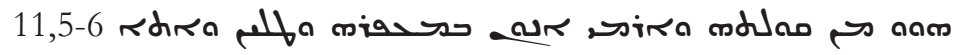

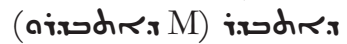

rheal PM: om. WG

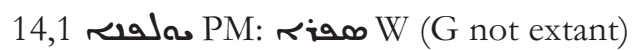

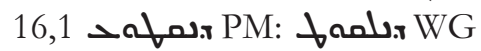

Significant readings in $\mathrm{W}$ and $\mathrm{G}$ absent in $\mathbf{P}$ and $\mathrm{M}$ :

2,2 post ram add. Nasa W, add. Ram Nasa $G$

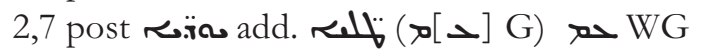

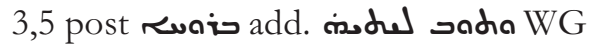

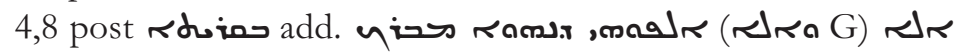
WG

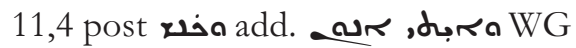

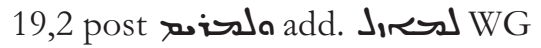

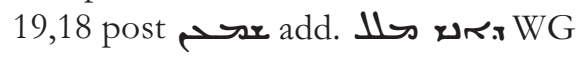


In a handful of instances $\mathrm{P}$ and $\mathrm{M}$ appear to preserve an original reading (i.e., the reading is not present in $\mathrm{W}$ and/or $\mathrm{G}$ but is present in the early versions and/or Gs):

2,12 ملح PM (cf. Gs: "with a shout"): om. WG

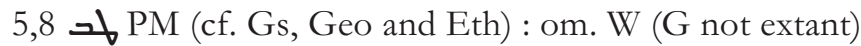

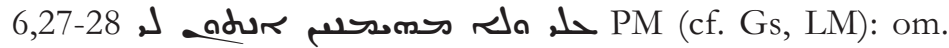
WG

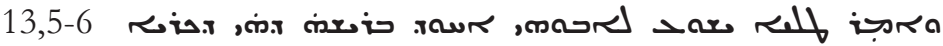

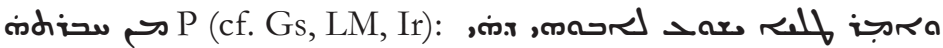

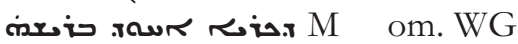

15,2 בran PM (cf. Gs, "with flattery"; LM, “to coax him”): om. W (G not extant)

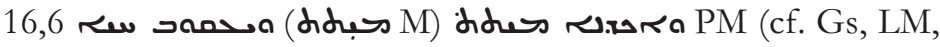
Eth): om. WG

19,8 حمسمصل PM (cf. Gs, Eth): om. WG

In another set of instances, $P$ and $M$ agree with $G$ against $W$, suggesting at least that $\mathrm{P}$ and $\mathrm{M}$ are descended from the same branch of transmission as $G$ or, perhaps, that the readings of the three Mss are superior to those in W. Agreements between P, M, and $\mathrm{W}$ against $\mathrm{G}$ are far less common.

Agreements between PM and G against W:

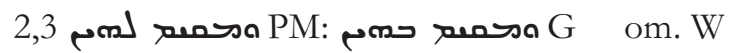

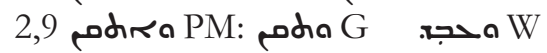

2,9 הMG: om. W

2,11 rdira PMG:

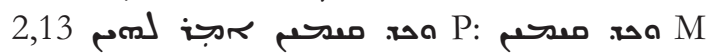

טה: مשתה

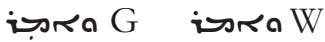

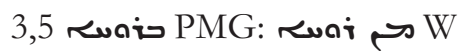

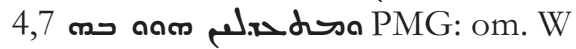

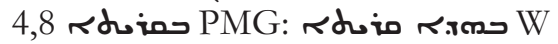

6,10 Rrm PMG: om. W

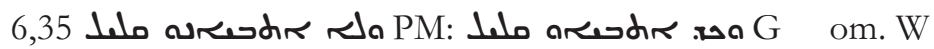

6,42 dorid PMG: om. W

9,5 , modusir PMG: , moduir W

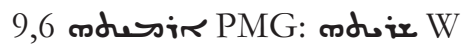

9,15 diam. PMG: om. W 
16,3 مre PMG: om. W

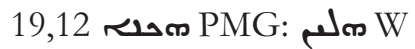

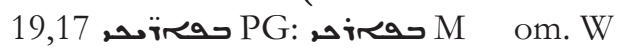

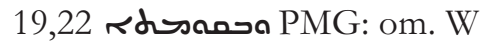

Agreements between PM and W against G:

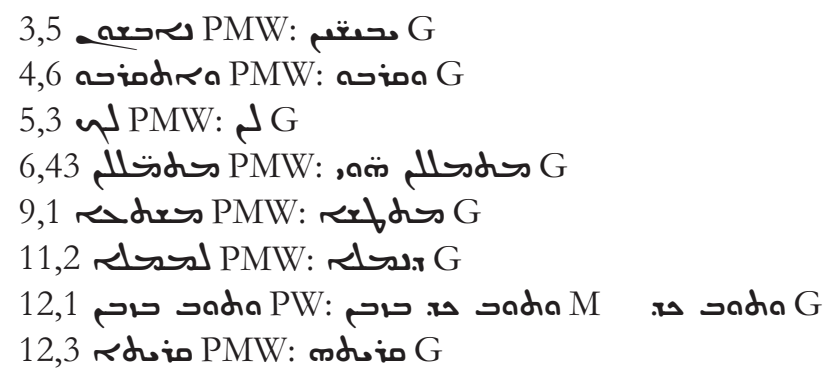

$\mathrm{P}$ is clearly related to $\mathrm{M}$. Both Mss present essentially the same text. However, the evidence does not indicate that one Ms is a copy of the other-M is the later Ms but it cannot be a copy of P; both must derive from a common exemplar. Though at some remove in time from $\mathrm{W}$ and $\mathrm{G}, \mathrm{P}$ and $\mathrm{M}$ add much to our knowledge of the Syriac tradition, particularly because they present us with a complete text of IGT without the lengthy lacunae found in the earlier Mss. Even so, it is clear that the Syriac tradition as we know it from all four Mss suffers from three deficiencies: 5:2 ends with "and not to curse" in the early versions and later witnesses; the "even more" Jesus promises to say in 6:2d is absent (see n. 73 below), and

M Mingana Syr. 105, paper, $315 \times 212$ mm., 263 fol., 2 col, 1832/1833: fol. 27v-29v. 81

This unpublished Ms contains the four gospels in the Harklean version with commentary (fol. $41^{\mathrm{r}}-208^{\mathrm{v}}$ ) along with an assortment of treatises. The Ms is important for providing correct readings for material missing or corrupt in $\mathrm{P}$ (including the blacked out material in 7,15-16, and a missing sentence in 19,7-8). Of course, the Ms is not perfect; it suffers from some errors of its own, including large omissions due to haplography $(2,13-14 ; 5,2-3 ; 6,49-51 ; 12,3$ and $19,4-5)$, and a number of smaller omissions, errors, and corruptions

${ }^{81}$ Mingana, Catalogue of the Mingana Collection, col. 254-61. 
(see below). Three corrections have been made, presumably by the copyist, at 6,$38 ; 7,5$; and 15,9 , and there is occasional use of vowels and abbreviations (principally for the third person singular possessive).

Deficiencies in $\mathbf{M}$ not present in $\mathbf{P}$ (minor omissions, spelling errors, and corruptions):

2,2 لتتص PWG: om. M

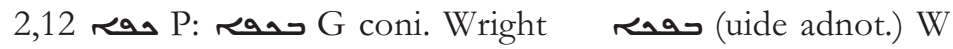
om. M

3,5 doogdrex P: dongdrax M dweadra WG

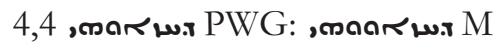

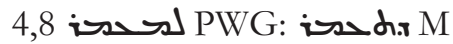

5,6 amourd PG: amened M rawed W

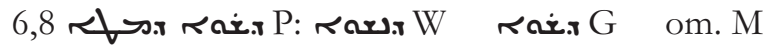

12 row: om. M (G not extant)

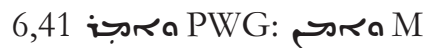

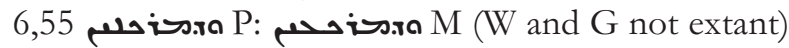

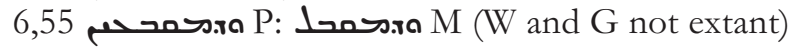

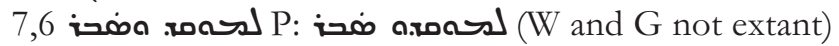

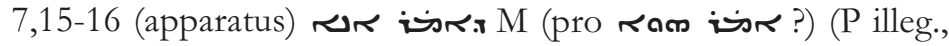

W and $G$ not extant)

7,18 ه P $\mathrm{PWG}$

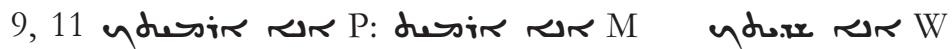

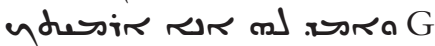

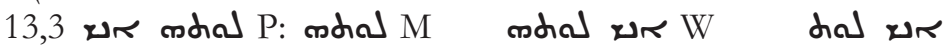
, $\mathrm{G}$

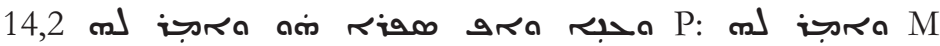
مrاجن (G not extant)

15,1 لهم له PW: om. M (G not extant)

19,3 لحس PWG: amodu M

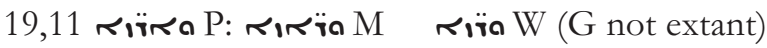


W London, British Library, Add. 14484, vellum, $10.5 \times 8.5$ inches, 36 fol., 2 col., $6^{\text {th }}$ cent.: fol. $14^{\mathrm{v}}-18^{\mathrm{v}} .82$

First published by William Wright in 1865, IGT is found here as part of a complex of Mary-related texts, beginning with Prot. Jas. at ch. 27 (fol. 12 $2^{\mathrm{r}}-14^{\mathrm{v}}$ ) and ending with Assum. Vir. (fol. 18v-47r). Ms $\mathrm{G}$ features the same arrangement of texts. IGT is incomplete in the Ms: it lacks several entire verses (6:3-4, 7:1-3, 8:2, and 15:3-4), parts of verses are missing, likely due to haplography $(6,5-6.18 .27-28.31$ $34.35)$, and several minor omissions are observable $(6,10.37 ; 11,6-7$; $15,2)$. There are a few notable scribal errors: the copyist himself has signaled a spoonerism with corrector's dots in 2,12 (حصa); there are three corruptions in 2,11,2,13, and 5,3; and Joseph is written instead of Jesus in 6,9. Note also the numerous agreements between $G$ and PM, at least some of which point to inferior readings in $\mathrm{W}$.

G Göttingen, Universitätsbibliothek, Syr. 10, parchment, $26.5 \times$ $21.5 \mathrm{~cm}, 37$ fol., 2 col., $6^{\text {th }}$ cent.: fol. $1^{\mathrm{v}}-4^{\mathrm{v}} .83$

The details of $G$ cannot be found in any of the Göttingen catalogues; fortunately, Baars and Heldermann have supplied the information. The Ms is said to have come from the Sinai, likely from St. Catherine's Monastery, ${ }^{84}$ the same location as a few Greek witnesses to IGT. As noted above, Alain Desreumaux recently demonstrated that several of the newly discovered fragmentary Mss from St. Catherine's (M26N and SP 78) belong to this Ms. The Göttingen pages of IGT suffer from some minor damage: in the title; 2,1.7; 6,37; and fol. $2^{\mathrm{r}}$ has a small hole in the right hand column made before writing. $G$ appeared in previous scholarship in Baars' collation (some errors of which are signaled in the apparatus in 2,$2 ; 6,9.15 .39 ; 7,18 ; 9,15 ; 11,2.4 ; 12,3 ; 16,5 ; 19,3)$ and in another collation made for Sever Voicu by Frederic Rilliet (who mistakenly reported that the Ms contained ch. 15). ${ }^{85}$

82 William Wright, Catalogue of Syriac Manuscripts in the British Museum Acquired Since the Year 1838 (London: British Museum, 1870), 98-9.

83 Baars and Heldermann, "Neue Materielen," 194-7.

84 Ibid., 192 n. 8.

${ }^{85}$ See Voicu, "Verso," 89-90. 
$\mathrm{G}$ is certainly related to $\mathrm{W}$, for it contains the same complex of

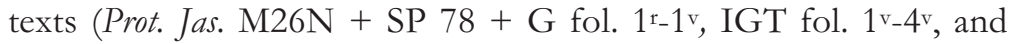
Assum. Vir. fol. $4 \mathrm{v}-37 \mathrm{v}$ ) and the two Mss share several large omissions in IGT (most notably 6:3-4 and portions of ch. 7); however, $\mathrm{G}$ does not share the scribal errors in $\mathrm{W}$ noted above and contains its own unique readings (see below) and large omissions (it lacks 5:2, 6:1, 6:2c-2d, and chs. 14 and 15). There are also several smaller omissions, some of which are due to scribal error $(2,8.13$; 6,5.12-13; 19,9-11.13-15.20-21). On three occasions (see 5,3; 6,10 and 9,1 ), only $G$ seems to preserve the correct reading, though the numerous agreements between G and PM may also point to areas where $\mathrm{G}$ is superior to $\mathrm{W}$.

Significant readings unique to G:

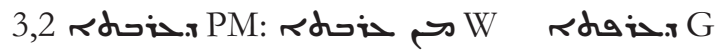

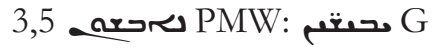

4,6 1 a PMW: :

5,3 थ PMW: $\mathrm{dG}$

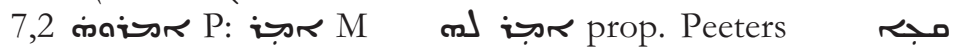
حبع

7,16,

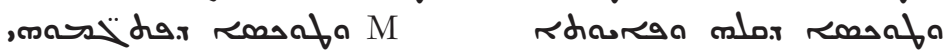

(W not extant)

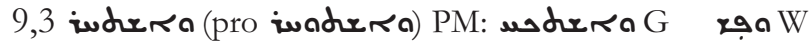

9,11 ante שradd. on a

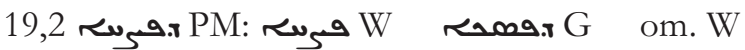

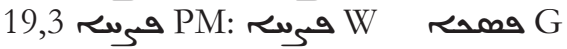




\section{BIBLIOGRAPHY}

Aasgaard, Reidar. The Childhood of Jesus: Decoding the Apocryphal Infancy Gospel of Thomas. Eugene, OR: Cascade Books, 2009.

Amann, Émile. “Apocryphes du Nouveau Testament." In vol. 1 of DBSup 1. Edited by L. Pirot and A. Robert, 460-553. Paris: Librairie Letouzey \& Ané, 1928.

Assemani, Stefano Evodio. Bibliothecae Apostolicae Vaticanae Codicum Manuscriptorum catalogus, Vol. 3, Reliquos Codices Chaldaicos sive Syriacos. Paris: Maisonneuve, 1926.

Baars, Wilhelm and Jan Heldermann. "Neue Materielen zum Text und zur Interpretation des Kindheitsevangeliums des PseudoThomas." OrChr 77 (1993): 191-226; 78 (1994): 1-32.

Bigaré, Christian. "L'achèvement des Écritures." In Introduction à la Bible. Vol. 5. Edited by Pierre Grelot and Christian Bigaré, 181211. Tournai: Desclée, 1977.

Brock, Sebastian P. Catalogue of the Syriac Fragments (New Finds) in the Library of the Monastery of Saint Catharine, Mount Sinai. Athens: Fondation du Sinaï, 1995.

Baumstark, Anton. Geschichte der syrischen Literatur mit Ausschluss der christlich-palästinensischen Texte. Bonn: A. Marcus \& E. Webers Verlag, 1922.

Budge, Ernest A. Wallis, ed. The History of the Blessed Virgin Mary and the History of the Likeness of Christ. 2 vols. London: Luzac \& Co., 1899.

Burke, Tony. De infantia Iesu enangelium Thomae graece. CCSA 17. Turnhout: Brepols, 2010.

Carney, James. "Two Old Irish Poems.” Eriu 18 (1958): 1-43.

Chartrand-Burke, Tony. "The Infancy Gospel of Thomas: The Text, its Origins, and its Transmission.” Ph.D. diss., University of Toronto 2001.

- "The Greek Manuscript Tradition of the Infancy Gospel of Thomas,' Aporypha 14 (2004): 129-51. 
Cotelier, Jean Baptiste. SS. Patrum qui temporibus apostolicis floruerunt. $2^{\text {nd }}$ ed. Antwerp: Huguetanorum sumtibus, 1698.

Cowper, Benjamin Harris, ed. The Apocryphal Gospels and Other Documents Relating to the History of Christ. $4^{\text {th }}$ ed. 1867. Reprint, London: Frederic Norgate, 1874.

Cullmann, Oscar. "Infancy Gospels." In New Testament Apocrypha, Vol. 1, Gospels and Related Writings. Edited by Wilhelm Schneemelcher, 414-69. Translated by R. McL. Wilson. Rev. ed. Louisville, Ky.: Westminster John Knox, 1991.

Delatte, Armand. "Évangile de l'enfance de Jacques: Manuscrit No. 355 de la Bibliothèque Nationale." In Anecdota Atheniensia, Vol. 1, Textes grecs inédits relatifs à l'bistoire des religions. Edited by Armand Delatte, 264-71. Paris: Edouard Champion, 1927.

Desreumaux, Alain. "Un manuscrit syriaque de Téhéran contenant des apocryphes." Apocrypha 5 (1994): 137-64. . "Les apocryphes syriaques sur Jésus et sa famille." In Les apocryphes syriaques. Etudes syriaques 2. Edited by M. Debie, A. Desreumaux, C. Jullien, and F. Jullien, 51-69. Paris: Geuthner, 2005.

"Deux anciens manuscrits syriaques d'oeuvres apocryphes dans le nouveau fonds de Sainte-Catharine du Sinaii: La Vie de la Vierge et Les Actes d'André et Mathias." Apocrypha 20 (2009): 115-36.

de Santos Otero, Aurelio. Das kirchenslavische Evangelium des Thomas. PTS 6. Berlin: De Gruyter, 1967.

de Strycker, Émil. La forme la plus ancienne du Protévangile de Jacques. Subsidia Hagiographica 33. Bruxelles: Société des Bollandistes, 1961.

Duensing, Hugo. “Mitteilungen 58.” TLZ 36 (1911): 637.

Elliott, James Keith. The Apocryphal New Testament: A Collection of Apocryphal Christian Literature in an English Translation. Oxford: Clarendon Press, 1993.

Garitte, Gérard. "Le fragment géorgien de l'Évangile de Thomas." RHE 51 (1956): 511-20. 
Geerard, Maurice. Clanis apocryphorum Noui Testamenti. Turnhout: Brepols, 1992.

Genequand, Charles. "Vie de Jésus en Arabe." In Écrits Apocryphes Chrétiens, vol. 1. Edited by François Bovon and Pierre Geoltrain, 207-238. Paris: Gallimard, 1997.

Gero, Stephen. "The Infancy Gospel of Thomas: A Study of the Textual and Literary Problems.” NovT 13 (1971): 46-80.

"Apocryphal Gospels: A Survey of Textual and Literary Problems." $A N R W$ 25.2. Part 2. Edited by H. Temporini and W. Haase, 3978-84 New York: De Gruyter, 1988.

Goodman, A. E. "The Jenks Collection of Syriac Manuscripts in the University Library, Cambridge." JRAS (1939): 581-600.

Graf, George. Geschichte der christlichen Arabischen Literatur. Vol. 1. Vatican City: Biblioteca Apostolica Vaticana, 1944.

Grébaut, Sylvain. "Les miracles de Jésus: Texte éthiopien publié et traduit." PO 12.4 (1919): 555-652.

Henkey, Charles H. "Bible, Apocrypha of the New Testament." In New Catholic Encyclopedia. Vol. 2. Edited by Catholic University of America, 404-41. New York: McGraw-Hill, 1967.

Herbert, Máire and Martin McNamara, "A Versified Narrative of the Childhood Deeds of the Lord Jesus." In Aporrypha Hiberniae, t. 1: Evangelia infantiae, vol. 1. CCSA 13. Edited by Martin McNamara et al., 443-83. Turnhout: Brepols, 2001.

Horn, Cornelia B. and Robert R. Phenix. "Apocryphal Gospels in Syriac and Related Texts Offering Traditions about Jesus." In Jesus in apokryphen Evangelienüberlieferungen. Edited by Jörg Frey and Jens Schröter, 527-55. WUNT 254. Tübingen : Mohr Siebeck, 2010.

James, Montague Rhodes. "Review of Évangiles apocryphes, vol. 2, by Paul Peeters." JTS 16 (1915): 268-73. . “The Gospel of Thomas." JTS 30 (1928): 51-4.

Lambeck, Peter. Commentariorum de augustissima Bibliotheca Caesarea Vindobenensi liber septimus. Vienna: Typis M. Cosmerovii, 1675. 
Leloir, Louis. Saint Éphrem, Commentaire de l'Évangile concordant, texte syriaque (Manuscrit Chester Beatty 709). Folios Additionnels. CBM 8(b). Leuven: Peeters, 1990.

Martin, Raymond A. Syntactical Evidence of Semitic Sources in Greek Documents. Septuagint and Cognate Studies 3. Cambridge, Mass: Society of Biblical Literature, 1974.

Meyer, Arnold. "Kindheitserzählung des Thomas." In Neutestamentlichen Apokryphen. Edited by Edgar Hennecke, 93102. $2^{\text {nd }}$ ed. Tübingen: J. C. B. Mohr, 1924.

Mimouni, Simon Claude. "Genèse et évolution des traditions anciennes sur le sort final de Marie. Étude de la tradition littéraire copte.” Marianum 42 (1991): 69-143.

. "Vies de la Vierge. État de la question." Apocrypha 5 (1994): 211-48.

Mingana, Alphonse. "Woodbrook Studies 5: Vision of Theophilus." BJRL 13 (1929): 383-74 (reprinted in id., Woodbroke Studies fascicle 5. Cambridge: W. Heffer \& Sons, Ltd. 1931).

. Catalogue of the Mingana Collection of Manuscripts. Vol. 1. Cambridge: W. Heffer \& Sons, Ltd., 1933.

Mingarelli, Giovanni Luigi. "De Apocrypho Thomae Evangelio...epistola." In Nuova Raccolta d'opuscoli scientifici e filologici, vol. 12. Edited by A. Calogiera, 73-155. Venice, 1764.

Naffah, Charles. "Les 'histoires' syriaques de la Vierge: traditions apocryphes anciennes et récentes." Apocrypha 20 (2009): 13788.

Nau, François. "La version syriaque de la vision de Théophile sur le séjour de la Vierge en Egypte." ROC 15 (1910): 125-32.

Nicolas, Michel. Études sur les évangiles apocryphes. Paris: Michel Lévy Frères, 1866.

Noja, Sergio. "L'Évangile arabe apocryphe de Thomas, de la 'Biblioteca Ambrosiana' de Milan (G 11 sup)." In Biblische und Judistische Studien: Festschrift für Paolo Sacchi. Judentum und Umwelt 29. Edited by Angelo Vivian, 681-90. Paris: Peter Lang, 1990. 
. "À propos du texte arabe d'un évangile apocryphe de Thomas de la Ambrosiana de Milan." In YAD-NAMA: im memoria di Alessandro Bausani. Vol. 1. Edited by Biancamana Scarcia Amoretti and Lucia Rostagno. 335-41. Rome: Bardi Editore, 1991.

Peeters, Paul. Évangiles apocryphes. Vol. 2. Textes et documents pour l'étude historique du Christianisme 18. Edited by Charles Michel and Paul Peeters. Paris: Librairie Alphonse Picard \& Fils, 1914.

Petersen, William L. Tatian's Diatessaron: Its Creation, Dissemination, Significance, and History in Scholarship. VGSup 25. Leiden et al.: E. J. Brill, 1994.

Philippart, Guy. "Fragments palimpsestes latins du Vindobonensis 563 (Ve siècle?): Évangile selon S. Matthieu, Évangile de Nicodème, Évangile de l'Enfance selon Thomas." AnBoll 90 (1972): 391-411.

Philothée du Sinaï, Nonveaux manuscrits syriaques du Sinaï (Monastère Sainte Catharine, Archevêché du Sinaï, Pharan et Raitho). Athens: Fondation du Sinaï, 2008.

Provera, Mario E. Il Vangelo arabo dellinfanzia secondo il Ms. Laurenziano orientale (n. 387). Jerusalem: Franciscan Printing Press, 1973.

Rife, John Merle. “The Mechanics of Translation Greek.” JBL 52 (1933): 245-52.

Rosén, Thomas. The Slavonic Translation of the Apocryphal Infancy Gospel of Thomas. Acta Universitatis Upsaliensis, Studia Slavica Upsaliensia 39. Uppsala: Almqvist \& Wiksell International, 1997.

Saintyves, Pierre. "De la nature des évangiles apocryphes et de leur valeur hagiographique." RHR 106 (1932): 435-57.

Schneider, Gerhard. Apokryphe Kindheitsevangelien. New York: Herder, 1995.

Scher, Adai. "Notice sur les manuscrits syriaques et arabes conservés à l'archêveché chaldéen de Diarbékir." JA 10th series 10 (1907): 331-62; (1907): 385-431. 
. "Notice sur les manuscripts syriaques et arabes conservés dans la bibliothèque de l'évêché chaldéen de Mardin." Revue des Bibliothèques 18 (1908): 64-95.

Sike, Henry. Evangelium Infantiae; vel, Liber Apocryphus de Infantia Salvatoris; ex manuscripto edidit, ac Latina versione et notis illustravit Henricus Sike. Utrecht: Halman, 1697.

Simon, Richard. Nouvelles observations sur le texte et les versions $d u$ Nouveau Testament. 1695. Reprint, Frankfurt am Main: Minerva, 1973.

Smith Lewis, Agnes. Apocrypha Syriaca. The Protevangelium Jacobi and Transitus Mariae with Texts from the Septuagint, the Coran, the Peshitta, and from a Syriac Hymn in a Syro-Arabic Palimpsest of the fifth and other centuries (Studia Sinaitica No. XI). London: C. J. Clay, 1902.

Thilo, Ioannis Caroli. Codex Apocryphus Novi Testamenti. Vol. 1. Leipzig: Vogel, 1832.

Tischendorf, Constantin von. Evangelia Apocrypha. $2^{\text {nd }}$ ed. Leipzig: H. Mendelsohn, 1876.

Tischendorf, Constantin. "Rechenschaft über meine handschriftlichen Studien auf meiner wissenschaftlichen Reise von 1840 bis 1844." In Jahrbücher der Literatur 114, 45-58. Vienna: Carl Gerold Anzeigeblatt, 1846.

Turner, Nigel. Grammatical Insights into the New Testament. Edinburgh: T. \& T. Clark, 1965.

van Aarde, Andries G. "Die Griekse manuskrip van die Kindheidsevangelie van Tomas in Kodeks Sinaïtikus (Gr 453) vertaal in Afrikaans." Hervormde Teologiese Studies / HTS Theological Studies 61 (2005): 491-516.

van Rompay, Lucas. "De ethiopische versie van het Kindsheidsevangelie volgens Thomas de Israëliet." In Enfant dans les civilisations orientales. Edited by A. Théodoridès, P. Naster, and J. Riesl, 119-32. Leuven: Editions Peeters, 1980.

Variot, Jean. Les Évangiles apocryphes: Histoire littéraire, forme primitive, transformations. Paris: Berche \& Tralin, 1878. 
Voicu, Sever J. "Notes sur l'histoire du texte de l'Histoire de l'enfance de Jésus." Aporrypha 2 (1991): 119-32.

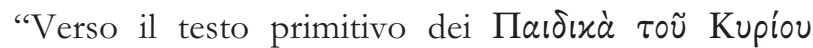

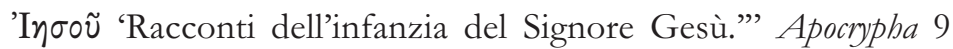
(1998): 7-95. 14 (2004): 13-21.

Walker, Alexander. Apocryphal Gospels, Acts and Revelations. Edinburgh: T. \& T. Clark, 1870 (=The Ante-Nicene Christian Library. Vol. 16. Edited by Alexander Roberts and James Donaldson).

Wright, William. Contributions to the Apocryphal Literature of the New Testament. London: Williams \& Norgate, 1865. Catalogue of Syriac Manuscripts in the British Museum Acquired Since the Year 1838. London: British Museum, 1870. 


\section{TEXT AND Translation}


A story about the childhood and upbringing of the Lord Jesus Christ and about the wonders which he performed in that time. ${ }^{1}$

$2^{2} 1$ Now when the boy Jesus Christ was five years old, he was playing at the ford of streams of water. And he was catching the waters ${ }^{3}$ and directing them in channels and establishing them into pools. ${ }^{4} \mathrm{He}$ was making the waters become clear and bright. ${ }^{5}$

2 Taking soft clay from the wet ground, he molded $^{6}$ twelve birds. It was the Sabbath and many children were with him.

3 But one of the Jews had seen him ${ }^{7}$ making these things and went to his father Joseph ${ }^{8}$ and incited $<$ him $>9$ against Jesus, and said to him ${ }^{10}$ : "On the Sabbath he molded clay and fashioned clay birds, ${ }^{11}$ something that is not lawful on the Sabbath."

${ }^{1}$ M lacks "the Lord." In P, the title precedes the Garshûni infancy material but it appears directly before the IGT text in M. W and G have "The childhood of the Lord Jesus." G, having suffered some damage here, appears to add "Christ" (cf. the explicit).

2 The Syriac and other early versions lack ch. 1 of the Greek text.

${ }^{3} \mathrm{~W}$ and $\mathrm{G}$ have "and was catching and confining the waters."

${ }^{4}$ For "establishing them into pools" W has only "and making them enter pools." $M$ and $G$ have the lengthier "and making them enter in channels and establishing them (G: by them) into pools."

${ }^{5} \mathrm{~W}$ and $\mathrm{G}$ have "pure and virtuous." Both of these words share the same root, suggesting perhaps that the second is a corruption.

6 P has "and he molded."

$7 \mathrm{~W}$ and G add "with the children," a reading found also in Sw as well as Gs, Geo, Eth, and LV.

${ }^{8} \mathrm{~W}$ and G have "told Joseph."

${ }^{9} \mathrm{P}$ and $\mathrm{M}$ have a feminine object here.

${ }^{10} \mathrm{G}$ lacks "and incited him against Jesus, and said to him," perhaps due to scribal error.

${ }^{11}$ W simply has "and made birds." 


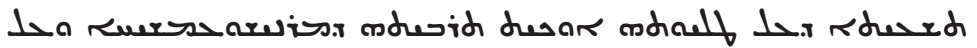

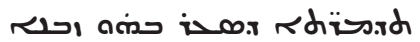

12

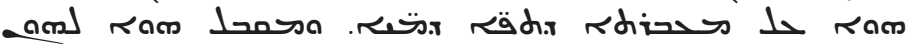

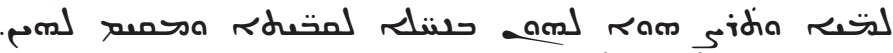

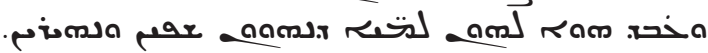

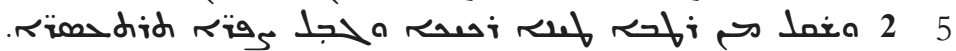

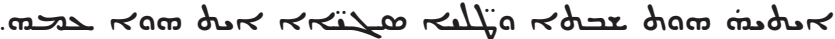

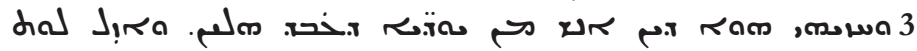

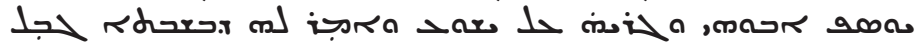

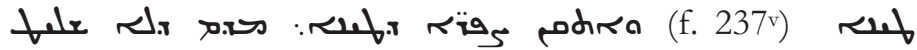
10

PMWG

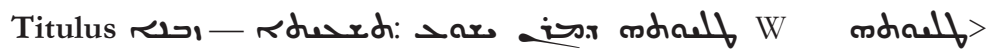

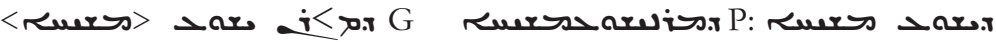
$\mathrm{M}$

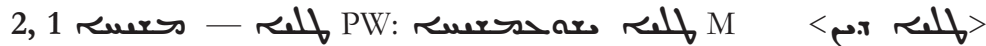

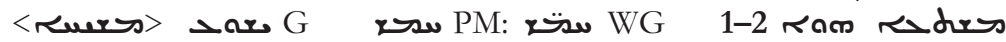

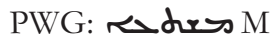

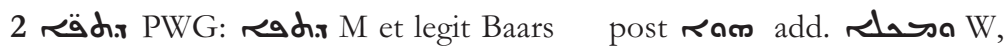
add. ram Rlasa $G$

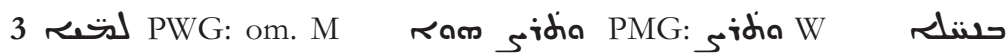
حسلم مذخد מan $M$ مדمعק لهم PM PM : om. W

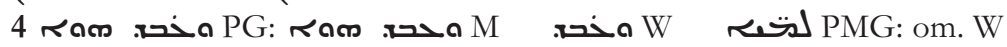

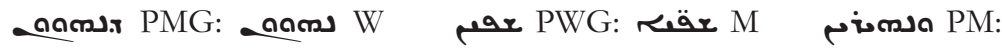
متصن WG

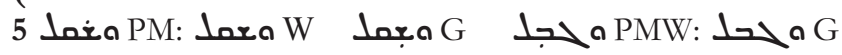

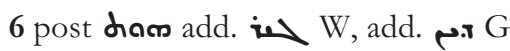

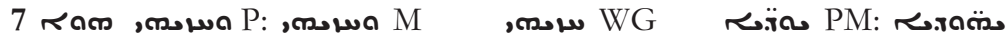

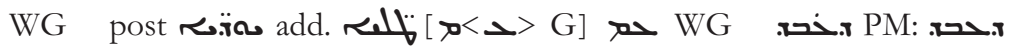

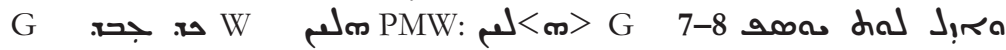
PM:

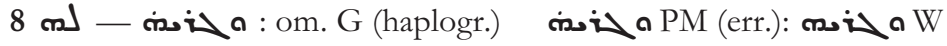

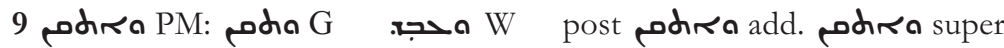
lin. M r. PMG: om. W 
4 Joseph came and rebuked him, and said to him: "Why are you making these things in this way?"12 Then Jesus clapped his hands noisily ${ }^{13}$ and made the birds fly away before these things that he said. ${ }^{14}$ While they were rising, he said to them ${ }^{15}$ : "Go, fly, and be ${ }^{16}$ mindful of me, living ones." And these birds went away and flew, ${ }^{17}$ twittering.

5 But when that Pharisee saw [it] he was amazed ${ }^{18}$ and went and told his friends.

31 The son of Hannān the scribe was also with Jesus, and he took a willow ${ }^{19}$ branch and broke down the pools and let the waters escape ${ }^{20}$ that Jesus had gathered together, and dried up their pools.

${ }^{12}$ For "in this way" M, W, and G have "on the Sabbath," a reading supported by Sw and Gs, Geo, Eth, and LV.

$13 \mathrm{~W}$ and G (along with Sw) omit "noisily." Gs has "with a shout."

${ }^{14} \mathrm{~W}$ has "that they said," though Wright suspects "that he said" is the correct reading. Gs and Geo have "in front of everyone," which is similar to Sw's "before all the people."

$15 \mathrm{~W}$ omits "while they were rising"; $\mathrm{G}$ is a partial witness to the reading but is corrupt with: "while they were rising and he said." M breaks off here and resumes after Jesus' command to the birds.

${ }^{16} \mathrm{P}$ erroneously has the verb in the feminine here.

${ }^{17} \mathrm{~W}$ and G (along with Sw) omit "and flew."

${ }^{18} \mathrm{~W}$ adds "greatly."

${ }^{19} \mathrm{G}$ has the synomym حiح whereas P, M, and W have حنح م.

${ }^{20} \mathrm{~W}$ has "leaked out and broke down and let the waters escape." G has "leaked and broke down the waters." The same reading is found in Sw. 


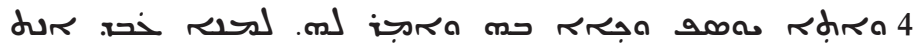

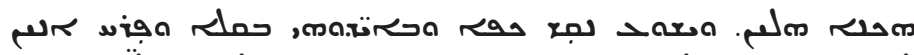

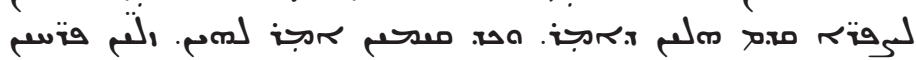

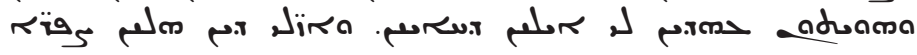

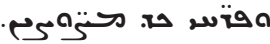

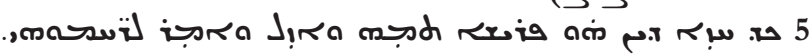

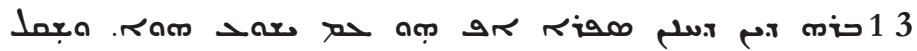

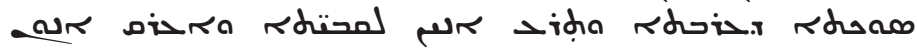

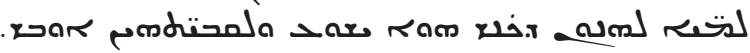

PMWG

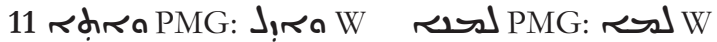

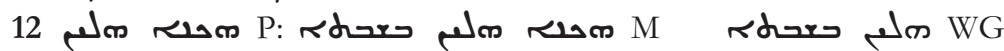

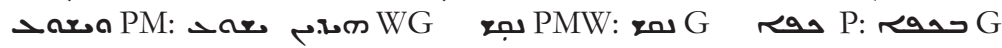

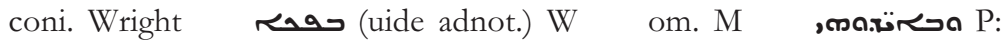

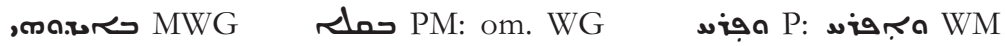

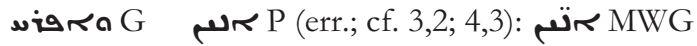

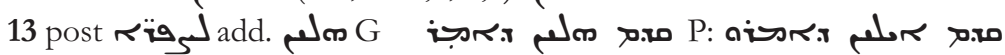

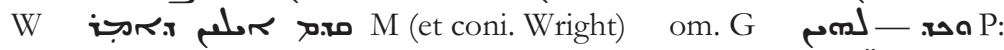

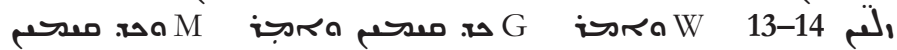

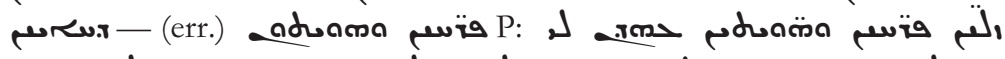

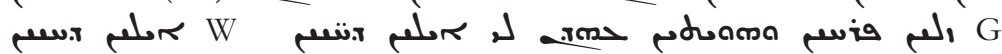
om. M

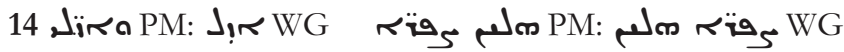

15 متح 15 PM: om. WG

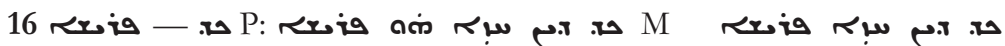

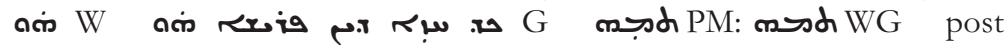

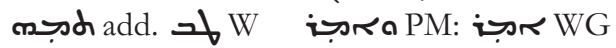

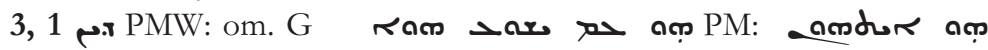

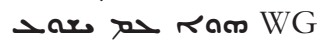

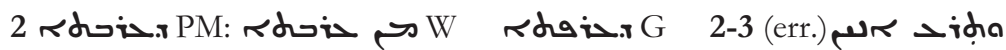
- P (cf. 2,12; 4,3):

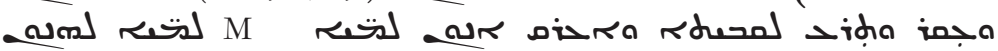

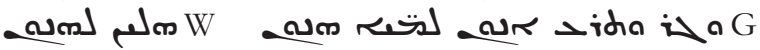

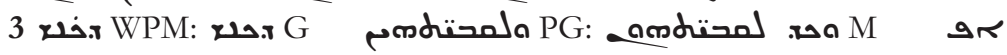
لمتصen post war add. *G 
2 Jesus said to him when he saw what had happened21: "Without roots shall be your branches 22 and your fruit shall dry up like a branch $^{23}$ torn off ${ }^{24}$ by the wind." 25

3 And that boy withered suddenly.

41 Again Jesus was going with his parents, ${ }^{26}$ and a boy came along running and knocked him to the ground. ${ }^{27}$ Jesus said to him: "You shall not go on your way." And suddenly that boy fell down and died. Those ${ }^{28}$ who saw him cried out and said: "Where was this boy born, that all his words are a deed?"

2 The family of that boy who died approached Joseph his father and were blaming him ${ }^{29}$ and saying ${ }^{30}$ : "As long as ${ }^{31}$ you have this boy, you cannot dwell with us in the village." 32

21 W has "what he did."

${ }^{22} \mathrm{~W}$ and $\mathrm{G}$ have "shoot." This agrees better with Gs, the early versions, and Sw.

23 W adds "of wood."

$24 \mathrm{~W}$ and G have "broken."

$25 \mathrm{~W}$ and $\mathrm{G}$ add "and is no more." The reading is found also in Sw.

${ }^{26} \mathrm{~W}$ and $\mathrm{G}$ have "his father," which is shared by Gs, the early versions, and Sw.

${ }^{27} \mathrm{~W}$ and G have "struck him with his shoulder" (or perhaps "on his shoulder"), a reading supported by Gs, Geo, LM, Sw, and Se. Perhaps P and M's reading of "the ground" (ארז ( (حi.).

28 W has "all."

${ }^{29}$ W lacks "and were blaming him."

${ }^{30} \mathrm{M}, \mathrm{W}$, and G add "to him."

${ }^{31} \mathrm{~W}$ and G lack "as long as" but the reading is supported in Sw.

${ }^{32} \mathrm{P}$ and $\mathrm{M}$ end the episode here. $\mathrm{W}$ and $\mathrm{G}$ continue with: "unless you teach him to bless." This clause is found also in Sw and Se, as well as Gs, Geo, Eth, and LM, though the versions (except Eth) add "and not to curse." 


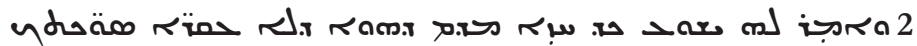

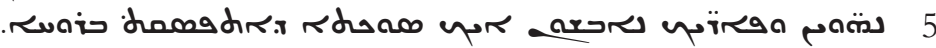
3

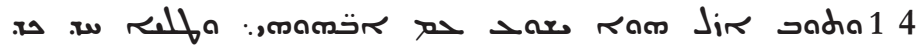

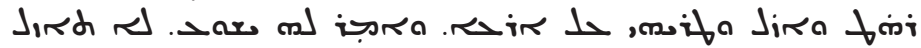

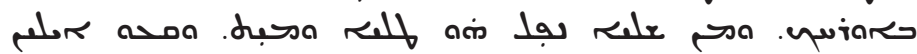

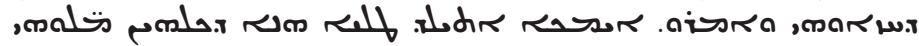
5

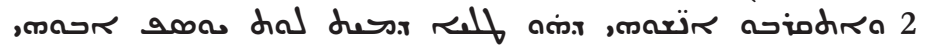

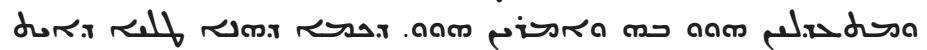

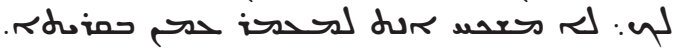

PMWG

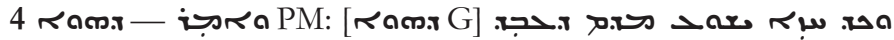

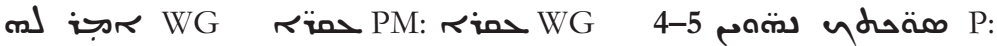

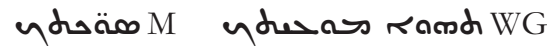

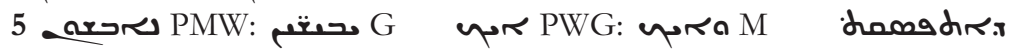

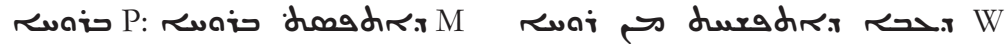

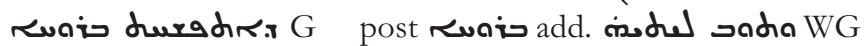

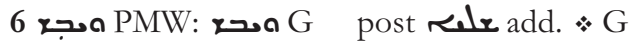

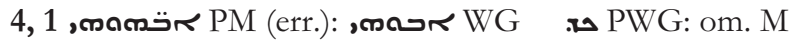

2 †

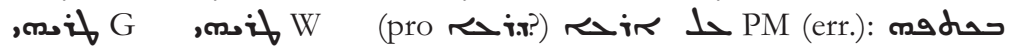

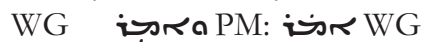

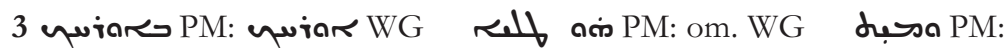

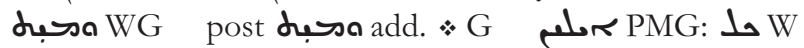

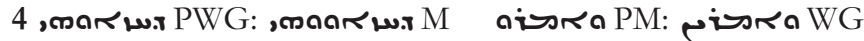

5 مستה : PWG (err.; cf. 2,12; 3,2)

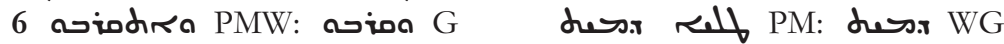
, rव PMG: om. W

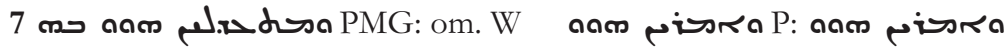

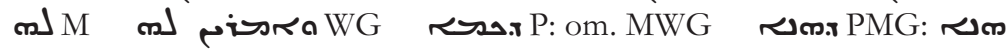
W דre PM: dor WG

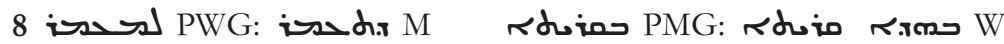

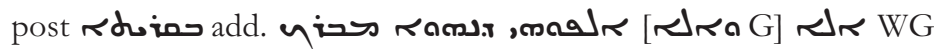


51 Joseph, having heard these things, approached ${ }^{33}$ the boy Jesus and was lecturing him, saying: "Why do you do these things? Why do you say these things? 34 The people are suffering and hating you." 35 The boy Jesus said to him: "If the words of my Father were not wise, he would not know [how] to instruct children." He spoke again: "If these were not children of a sinner, ${ }^{36}$ they would not be receiving a curse. These shall see ${ }^{37}$ their torment." Immediately those who were accusing him were blinded. ${ }^{38}$

2 Joseph became angry and seized him by his hand ${ }^{39}$ and pulled it hard. ${ }^{40}$ But [Jesus] answered and said to him: "It is enough that you should be seeking me and finding me; for you have acted ignorantly."

61 A teacher, whose name was Zacchaeus, heard him speaking with

${ }^{33} \mathrm{~W}$ and G have only "He (G: Joseph) approached" which is reflected in Gs, the early versions, Sw, and Se.

${ }^{34} \mathrm{M}$ lacks this question, perhaps due to homoeoarcton.

${ }^{35} \mathrm{G}$ has "us" in agreement with Gs and the early versions. M lacks "suffering."

${ }^{36} \mathrm{M}, \mathrm{W}$, and G have "If these were children of the bedchamber," a reading shared in Sw. For "bedchamber" (لעم " Peeters suggests "Gehenna" (几م/).

${ }^{37} \mathrm{M}, \mathrm{W}$, and $\mathrm{G}$ have "not see."

${ }^{38}$ In $\mathrm{G}$ the episode finishes here, resuming at 6:2.

39 "By his hand" (حسمוֹ) is a corruption unique to P and M. All

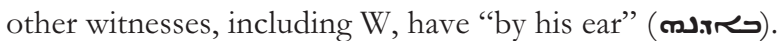

${ }^{40} \mathrm{~W}$ lacks "hard," though it is supported by Gs, Geo, Eth, and Sw. 


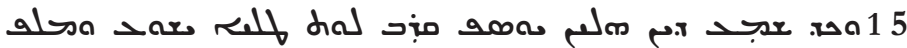

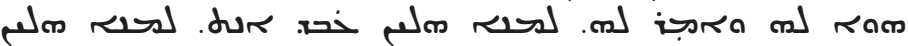

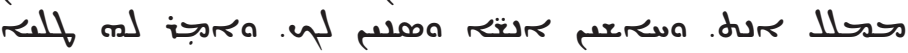

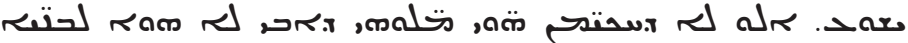
anm 5

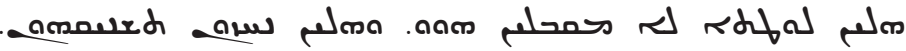

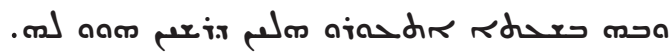
2

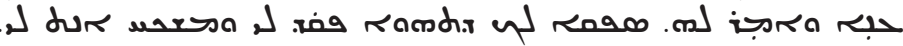

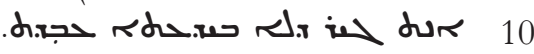

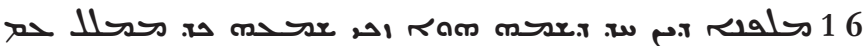

PMWG

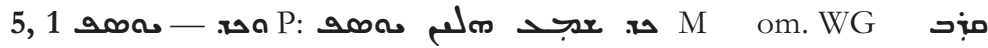

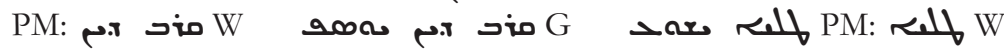
Gم

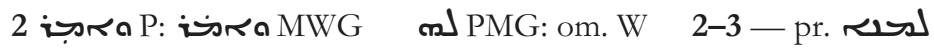

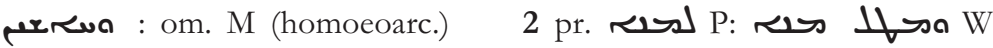

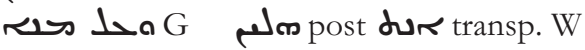

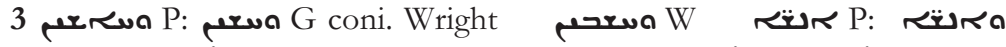

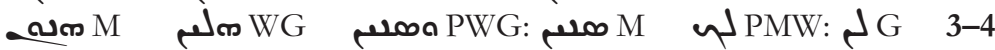

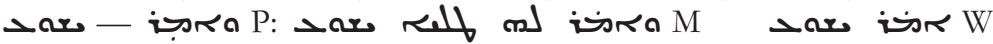

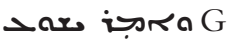

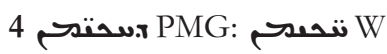

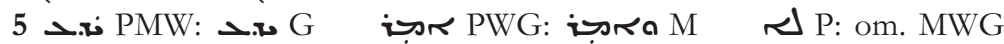

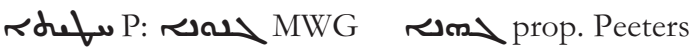

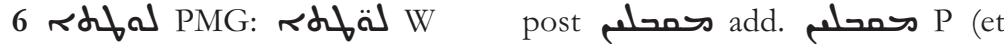

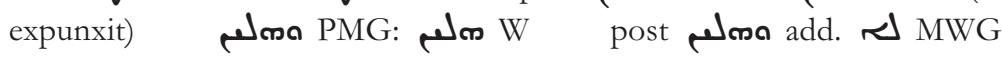

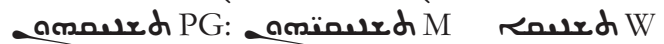

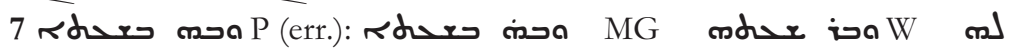
PWG: حدم M post add. *G

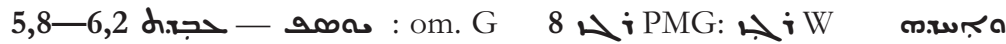

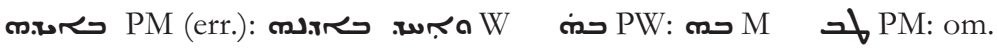

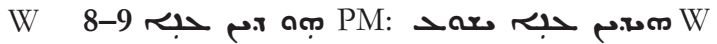

9 dur PM: om. W

10 post حجr. add. * M 
his father and said: "Oh stubborn boy! Why are you saying these things?" 41

2 He said to Joseph"2: "How long will you not wish to hand over this boy ${ }^{43}$ to learn to love children his age, honour old age, ${ }^{44}$ and to be in awe of elders, ${ }^{45}$ in order that the love of children ${ }^{46}$ may be with him and, moreover, that he may teach them?"

2a Joseph said" ${ }^{47}$ "Who is able to teach a boy like this? Do you ${ }^{48}$ not think that he deserves to attain ${ }^{49}$ the small cross to come?" 50

2b The boy ${ }^{51}$ answered and said to them ${ }^{52}$ : "Teacher, these words which you have now spoken ${ }^{53}$ - and they will be names of renown ${ }^{54}$ - I am a stranger to them; for I am outside of you, yet I dwell among you. Honour of the flesh ${ }^{55} \mathrm{I}$ have not. You [live] by the law and by the law you search. ${ }^{56}$

${ }^{41} \mathrm{~W}$ reads "Oh wicked boy!", agreeing with Sw (though Se has "stubborn"). Both M and W lack the following sentence. The entire first verse is missing in $G$ (see n. 38). Zacchaeus does not speak here at all in Gs and the early versions.

${ }^{42} \mathrm{G}$ reads here: "Zacchaeus the scribe began to say to his father."

${ }^{43} \mathrm{M}$ adds: "to him."

${ }^{44} \mathrm{~W}$ finishes the sentence at this point.

${ }^{45} \mathrm{G}$ lacks this item, likely due to homoeoarcton.

${ }^{46} \mathrm{P}$ has the corrupt reading "love of natural things." To solve the problem, Peeters suggests the emendation "love of men." $G$ and $M$ have "children" which agrees with Gs, the early versions, Sw, and Se.

47 W has "answered and said."

48 W has "does he."

${ }^{49} \mathrm{~W}$ and G have only "deserves," which, written alone, may be better translated "equal to." The word is lacking in M.

50 Only P has "to come."

51 G has "Jesus" and W has the erroneous "Joseph."

${ }^{52} \mathrm{P}$ and $\mathrm{M}$ have "to them the teacher," whereas W has the less problematic "to him the teacher"; G lacks all mention of an object.

53 "I have now spoken" is also possible; only W explicitly has "you."

${ }^{54} \mathrm{G}$ has the better reading: "these names which you name," which fits well with Gs, Geo, and LM, as well as Se, but not Sw. W has only "and these names."

55 W has "in the flesh."

${ }^{56} \mathrm{G}$ lacks this sentence. W finishes the sentence with "you remain," a reading supported in Se and LM; however; Sw also has "search." The entire sentence in M reads: "You [live] by the law, you search." 


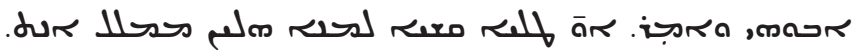
, لו 2

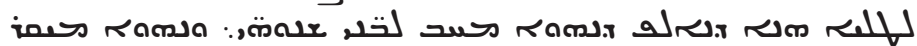

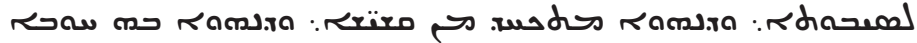

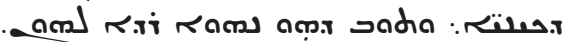

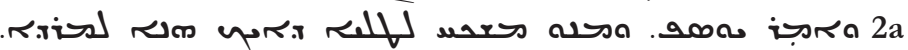

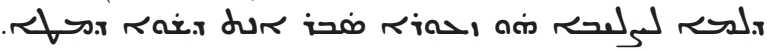
2b

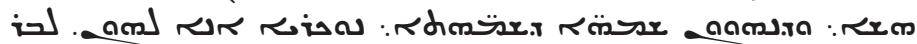
תרנה

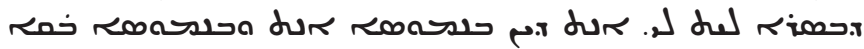

PMWG

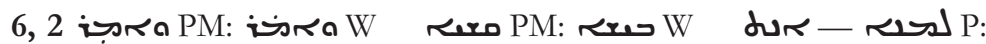
om. MW

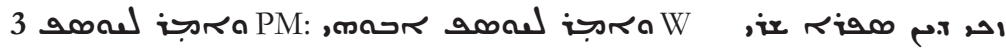

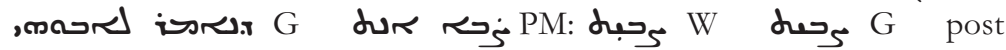

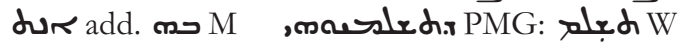

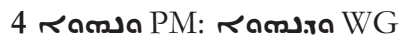

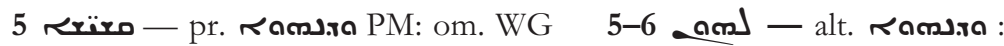
om. W

6 prop. Peeters

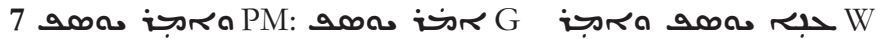

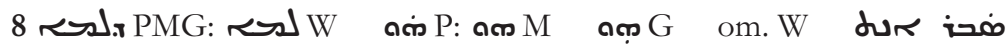

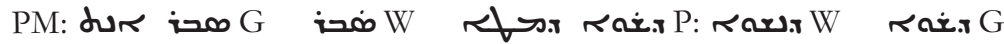
om. M

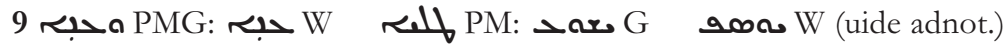

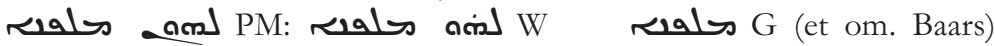

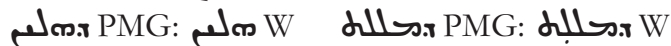

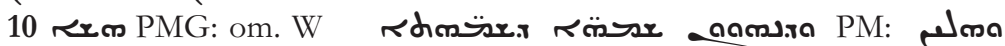

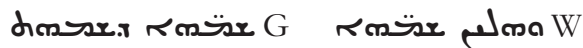

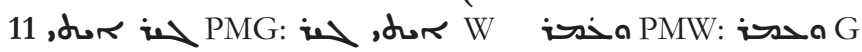

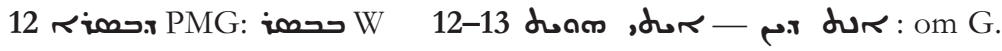

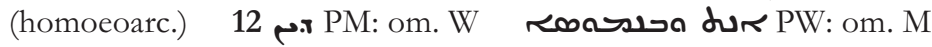

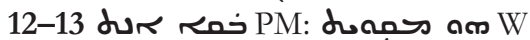


For when you were born, I was. ${ }^{57}$ But you think that you are my father. ${ }^{58}$ You shall learn from $<$ me $>59$ that teaching which no one else knows nor is able to teach. ${ }^{60}$ And that cross of which you speak, the one whose it is shall bear it. For when I am greatly exalted I shall lay aside that which is mixed in your race. For you do not know $<$ from $>61$ where I was born nor from where I am ${ }^{62}$; for I alone know you all ${ }^{63}$ truly-where ${ }^{64}$ you were born, how much time ${ }^{65}$ you have, and how much remains for you here." 66

2c When they heard [these words], they were amazed and cried out greatly ${ }^{67}$ and said: "Oh wonderful sight! Oh wonderful sound! Words like these we have never heard anyone speak-neither the priests, nor the Pharisees, nor the scribes. ${ }^{68}$ Where was this one born? And he is not yet fully five years of age ${ }^{69}$ and speaking such words! $<$ One $>$ has never seen the likes of this." 70

${ }^{57} \mathrm{G}$ lacks this sentence.

${ }^{58}$ For "father" Peeters suggests "master." W has "I think."

${ }^{59} \mathrm{P}$ and $\mathrm{M}$ have "from you (sing.)." $\mathrm{W}$ and $\mathrm{G}$ have "from me."

${ }^{60} \mathrm{M}$ has "you are not able to teach."

${ }^{61}$ P has "not."

${ }^{62} \mathrm{G}$ has "whence you are"; W lacks "where I was born nor from where," likely due to homoeoarcton.

${ }^{63} \mathrm{~W}$ lacks "you all"; G has simply "you."

${ }^{64} \mathrm{~W}$ and G have "when."

65 G adds "again."

${ }^{66} \mathrm{G}$ adds "I know." W has "when you were born and how much time you have to remain here." $G$ breaks off here (perhaps due to homoeoarcton) and continues at the start of 6:2e.

67 W lacks "greatly."

${ }^{68} \mathrm{~W}$ interchanges Pharisees and scribes.

${ }^{69} \mathrm{~W}$ lacks "not yet fully." The intent is to minimize Jesus' age- he has not yet completed his fifth year. Several of the other witnesses do something similar.

70 For "one" $\mathrm{P}$ and $\mathrm{M}$ have "among us," thereby rendering the sentence without a subject. 


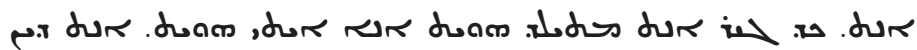

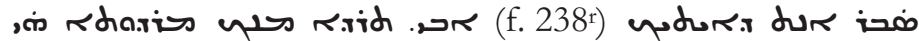
वं் 15

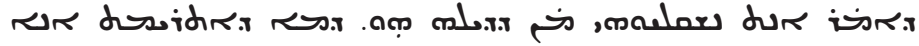

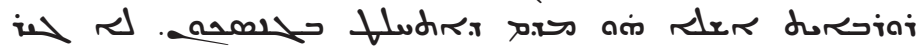
ن. Ror doritir

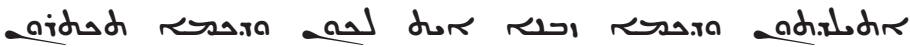

$$
\text { . nim }
$$

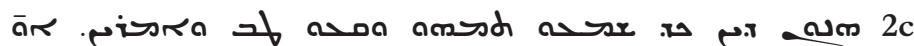

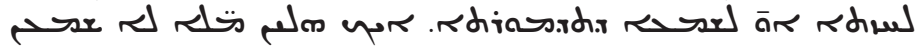
s

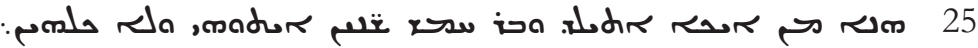

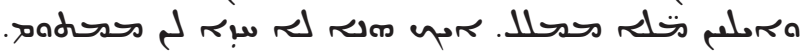

PMWG

13 אח גan PM: du

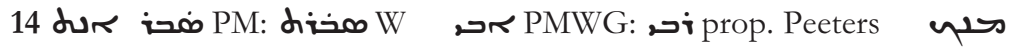

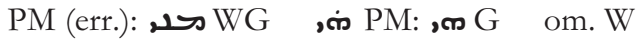

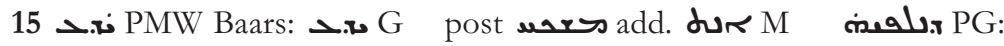

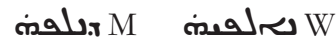

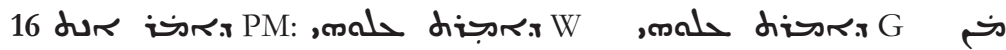

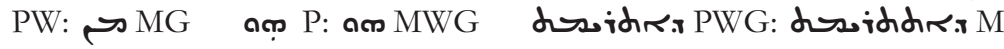
مr PMG: om. W

17 a คMG: om. W

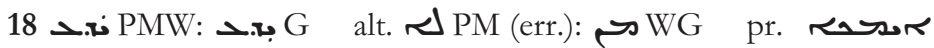

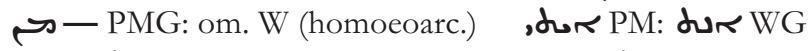

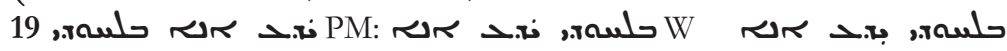

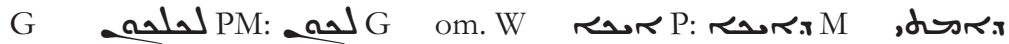
WG

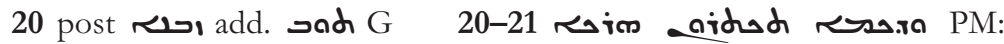

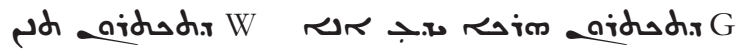

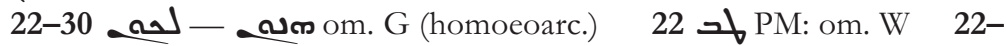

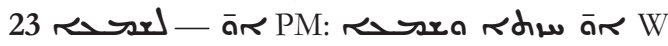

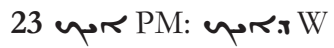

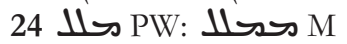

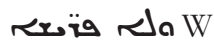

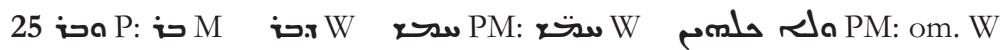

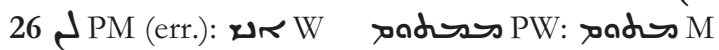

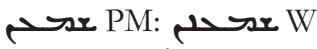

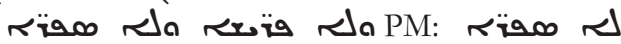


2d Again Jesus answered and said to them: "You wonder about me and do not believe me concerning what I have said to you. ${ }^{71} \mathrm{I}$ said that I know when you were born ${ }^{72}$; and I have even more to say to you." 73

2e When they heard [these words], they were silent and no one spoke. ${ }^{74} \mathrm{He}$ approached them again and said, laughing: "I laughed at you because you marvel at trifles and are becoming small in your mind."

2f They did not understand [even] a little. ${ }^{75}$ Zacchaeus the teacher said to the father of Jesus ${ }^{76}$ : "Bring him to $\mathrm{me}^{77}$ and I will teach him what is proper for him to learn." He coaxed him ${ }^{78}$ and made him go into <the> school. ${ }^{79}$ Yet, going in, he was silent. But Zacchaeus the scribe was beginning to teach him [starting] from Aleph, and was repeating to him many times and going [through $]^{80}$ all of the alphabet. He said to him that he should answer and speak after him, but he was silent. Then the scribe was angry

${ }^{71} \mathrm{~W}$ has only: "You wonder at what I have said to you." The longer reading is supported in Gs and LM, as well as Sw. The omission may be due to homoeoteleuton.

72 W lacks "born."

73 This "even more" is not extant in the Syriac Mss but is supplied in various ways by Gs, Eth, LM, and Geo.

${ }^{74} \mathrm{~W}$ and $\mathrm{G}$ have: "and were unable to speak." The verse then ends here in W.

${ }^{75} \mathrm{G}$ has "When they were comforted a little," which finds support in Gs, Geo, and Sw. The sentence is missing in W. Peeters links this sentence to the previous and reads "and you hardly have understanding."

76 W has only "to Joseph."

${ }^{77} \mathrm{~W}$ lacks "bring him to me" but the reading is supported in other witnesses.

${ }^{78} \mathrm{~W}$ lacks "coaxed him" but it finds support in Gs, Eth, and Geo.

79 P has "my school."

${ }^{80} \mathrm{~W}$ and G lack "and going [through]." Peeters translates this puzzling phrase as "listing them one by one." 


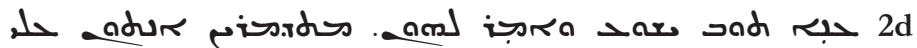

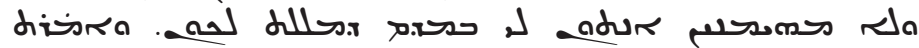
ז.i.

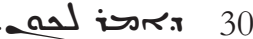

2e لا

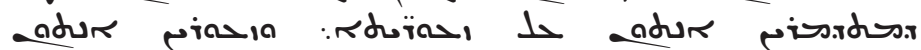
aderido

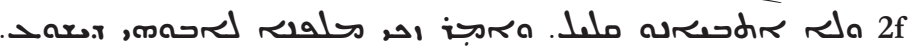
אים

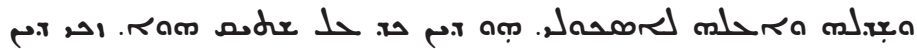

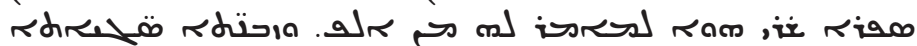

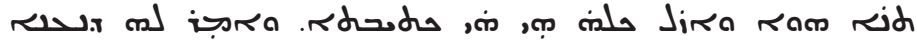

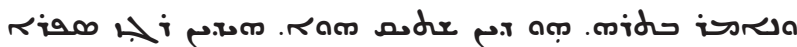

PMWG

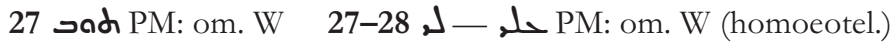

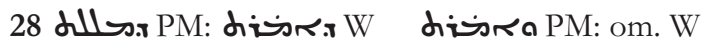

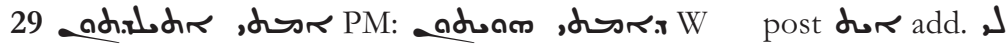
MW

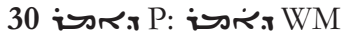

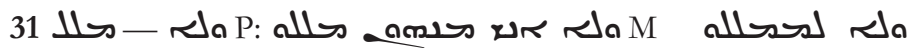

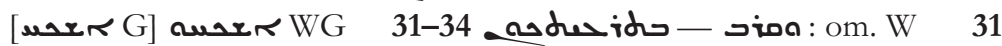
ممن P: MG

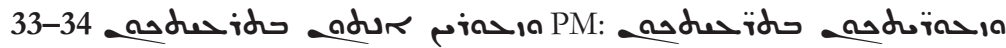
G

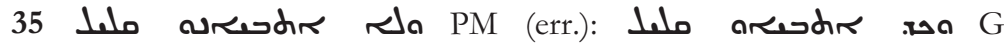

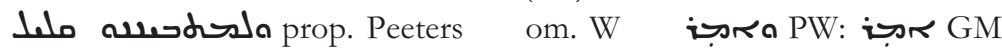

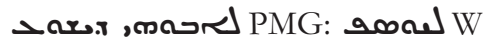

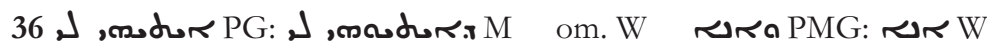

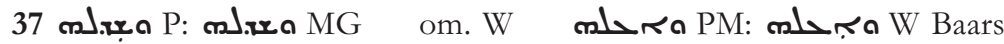

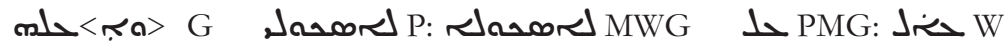
rowG: rad M

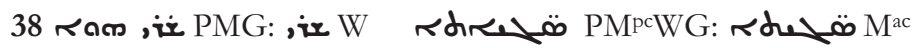

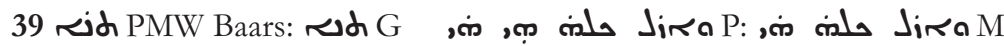

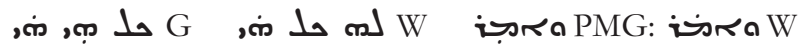
40 म 
and struck him with his hand upon his head. The boy said: "The smith's anvil, when struck repeatedly, ${ }^{81}$ may be instructed, yet is unfeeling. Likewise, ${ }^{82} \mathrm{I}$ can say those things which are spoken by you like a noisy gong 83 or a clanging cymbal. These do not reply with any sound nor do they have the power of knowledge and understanding." 84

3 Then Jesus said all the letters from Aleph to Tau ${ }^{85}$ with much wisdom. He answered again and said: "Those who do not know the Aleph, how do they teach the $<$ Beta $>$ ? 86 Hypocrites! Teach what is the Alpha and then ${ }^{87} \mathrm{I}$ will believe you concerning the Beta."

4 Then Jesus began ${ }^{88}$ to enquire concerning the form of each character, and he began with the letters. Concerning the first, for what reason it has many angles and characters, pointed, thick and prostrate and projected and extended; and their summits [are] gathered together and sharp and ornamented and erect and squared and inverted; and transformed and folded over and bent at their sides, and fixed ${ }^{89}$ in a triangle and crowned and clothed in life. ${ }^{90}$

71 Then Zacchaeus the scribe, amazed and astonished on account of all these names

\footnotetext{
81 W lacks "repeatedly."

82 Peeters suggests to read this word as "I" as in W, G, and Sw.

${ }^{83} \mathrm{G}$ breaks off here, resuming at 7:1.

${ }^{84} \mathrm{~W}$ shortens this exchange, reading "... which are spoken by you, with knowledge and understanding." The longer reading in $\mathrm{P}$ and $\mathrm{M}$ is supported in Sw and the early versions. W terminates here, resuming at

85 The use of the Hebrew letters in the teacher stories is one of the hallmarks of the Syriac tradition, though it is shared with the Old Latin and appears in various ways in some other witnesses. Oddly enough, Jesus switches the conversation here from Hebrew letters to Greek.

86 "Beta" is supplied by M. P has "empty," leading Peeters to emend the reading to "then don't teach the Beta."

${ }^{87} \mathrm{M}$ cuts off here and resumes after the following sentence.

${ }^{88} \mathrm{P}$, the only witness in this part of the verse, has the verb in the plural ("they began").

${ }^{89} \mathrm{M}$ has "receiving." Sw and Se also have "fixed."

${ }^{90}$ For "crowned and clothed in life" Peeters suggests "rounding and joining each other." "And clothed in life" does not appear in Sw and Se.
} $7: 4$. 


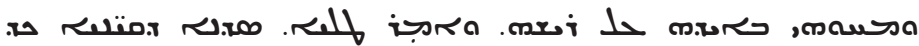
خلv

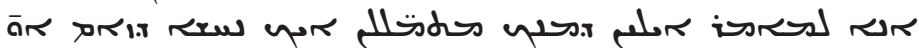
لم

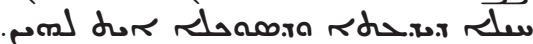

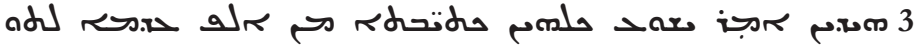

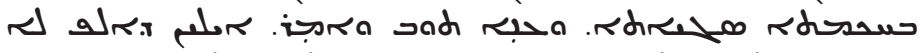

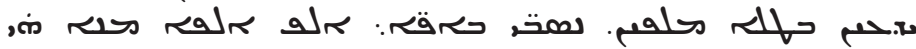

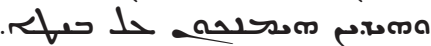
50

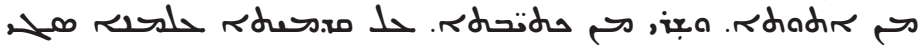

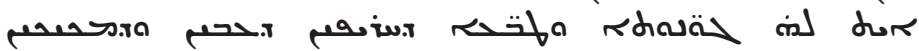

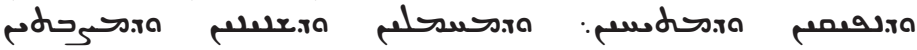

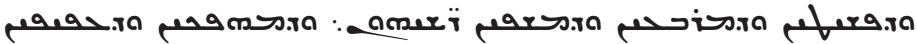

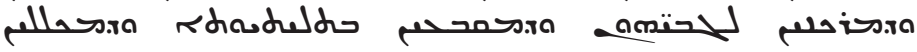

مים

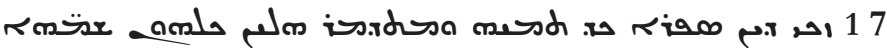

\section{PMWG}

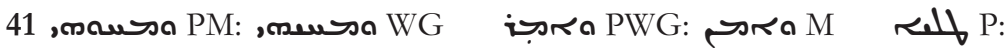

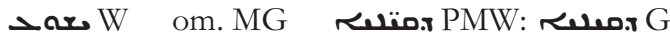

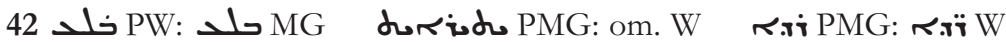

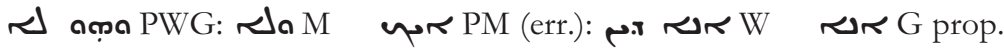
Peeters

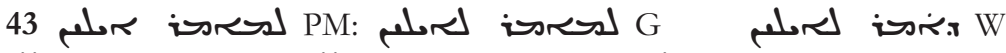

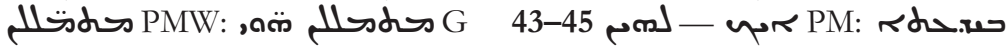
Naمra om. G

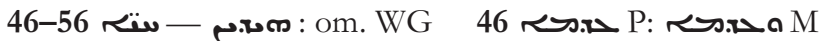
48 حلح P (err.): حسل

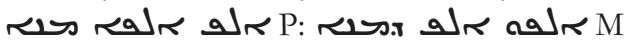

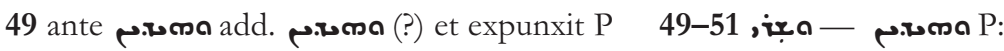

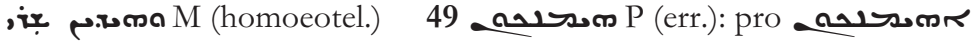

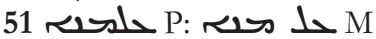

52 in id: om. M

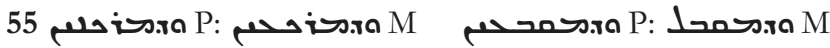

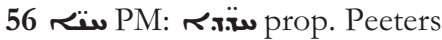

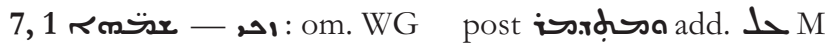


and the greatness of the speech, said <to him>91: "I have brought this $<$ matter $>92$ on myself." 93

2 "Take him away from me, $<\mathrm{I}>$ beg"9 of you. It is not right for this one to be this [way] on the Earth; truly, this one is worthy of a great cross. He is able to even set fire to fire. And I think that this one was born before the flood of Noah. What womb carried this one? Or what mother reared this one? For I cannot bear this one. I am in a great stupor because of him; and I am out of my mind. Wretched am I to think I had acquired a student; and, although I considered him a student, he was my teacher.

3 "Oh my friends! I cannot bear it. I am fleeing from the village; I cannot look upon him. By a little child I, an old man, am defeated. But what can I, who was defeated, say?95 < How, even from the beginning, I did not understand a thing this one was saying. ${ }^{96}$ Have mercy on me! I spoke clearly. ${ }^{97}$ My soul is before my eyes $>$ because of his voice and the example of his words. .8

91 "To him" is an emendation suggested by Peeters. M simply has "he said." W and $G$ lack much of this first verse. G continues from Zacchaeus' dialogue in 6:2f with "'like a brass resounding.' And at the greatness of his speech. He cried out and said" and then resumes at 7:3. W has "The scribe answered and said" and continues at 7:4.

92 "Matter" is an emendation. The Mss (P and M) read "ح ia, a corruption found also in Sw. The early versions have "shame" or "affliction."

93 Other versions (Gs, Geo, and Eth) begin the sentence with "Woe is me."

94 P lacks the pronoun here, preserving only the participle.

95 Two lines in the manuscript have been struck through and are unreadable. The material that follows is provided from M. The complete reading in $\mathrm{P}$ is: "Behold! Even from the beginning a thing...my soul is before my eyes." G reads: "Have mercy on me! I am dying! Clearly, my soul is before my eyes."

96 The Ms (M) has "I say."

${ }^{97} \mathrm{G}$, along with $\mathrm{Sw}$, has "I am dying."

${ }^{98} \mathrm{G}$ has "the order of his voice and the beauty of his words," which is

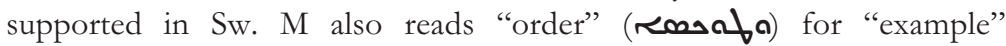
(rosa) 
محل .

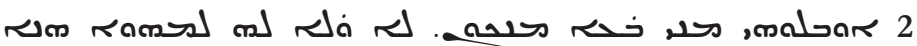

5

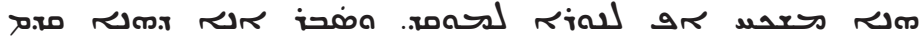

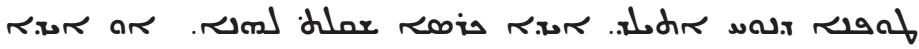

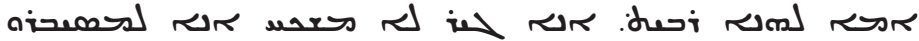

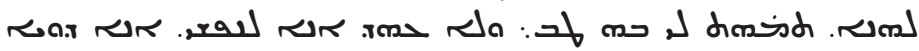

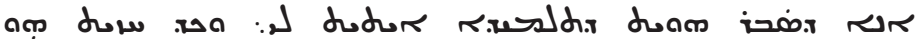
reals 1 ram ricestd

3 مiأ

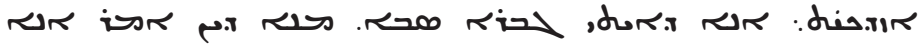

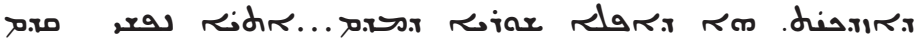

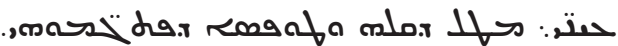

\section{PMWG}

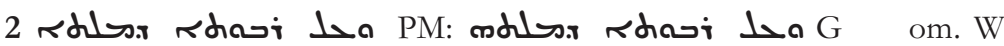

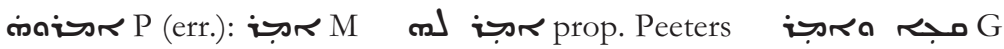

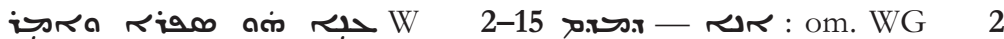

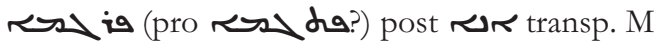

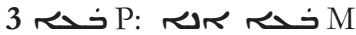

5 post dorivir add. Sרבת (et expunxit) M

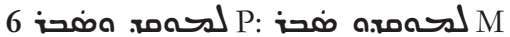

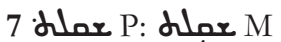

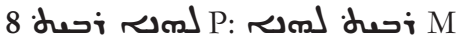

9 ר 9

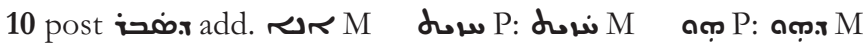

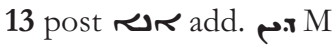

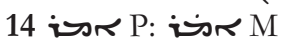

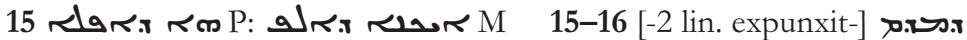

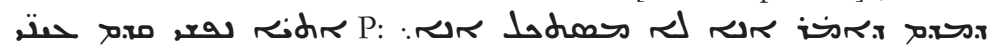
r M G G om. $\mathrm{W}$

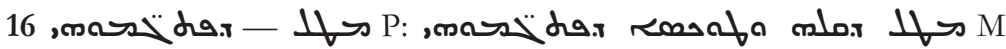

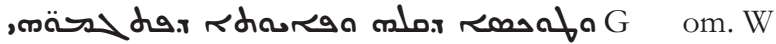


4 "This one99 is something great—either a god, or an angel; what, I should say I do not know."

81 Then the boy Jesus laughed and he <said $>100$ : "Let those in whom there is no fruit, produce fruit; and let the $<$ blind $>101$ see the living fruit, oh Judge!"102

2 Those who had fallen under the curse came alive and rose up. No one was daring to anger him again. ${ }^{103}$

91 Again, on the day of the Sabbath, 104 the boy Jesus was playing on a roof. 105 One of the children fell and died. When those children ${ }^{106}$ saw [what had happened], they ran away and Jesus $<$ stayed behind $>$ alone. ${ }^{107}$

2 The family of the dead boy ${ }^{108}$ seized him and < they $>$ said ${ }^{109}$ to him: "You threw the boy down from the roof and he died." 110 And the boy was < saying>111: "I did not throw him down." They were presumptuously ${ }^{112}$ accusing him.

${ }^{99}$ In $\mathrm{M}$ and $\mathrm{P}$, the object is linked to the previous verse with though the plural (Nor) would be more appropriate.

100 P reads "says."

101 "Blind" is supplied by M, W, and G. Peeters believes this to be the better reading and it receives support from Gs, Eth, and LM. P reads "the uprooters."

${ }^{102}$ For "oh Judge," W, G and Sw have "of condemnation."

103 This entire verse is missing in W, thus leaving all of Jesus' previous victims injured or dead.

104 Only the Syriac and early Latin (LM and LV) traditions place this event on the Sabbath.

${ }^{105} \mathrm{G}$ has "hiding with children on a roof." While "playing" is the likely reading, other witnesses to the text, including $\mathrm{Sw}_{w}$, agree that Jesus was with other children.

$106 \mathrm{M}$ and G have "the other children"; W has "the others."

$107 \mathrm{P}$ and $\mathrm{M}$ have "forced alone," a corruption of wodrr. W has "remained alone," G "was found alone."

${ }^{108} \mathrm{P}$ erroneously uses the feminine participle.

109 P erroneously has the singular ("he said").

$110 \mathrm{~W}$ and G have only "You threw the boy down."

111 P seems to lack the participle here. M, W, and G have "Jesus said."

$112 \mathrm{~W}$ and G lack "presumptuously." 
4

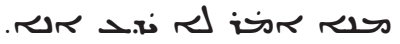

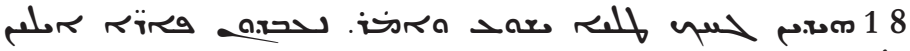

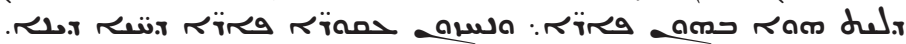

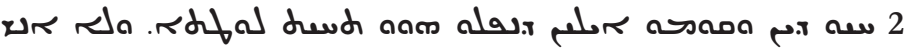

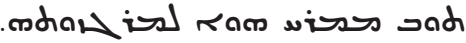

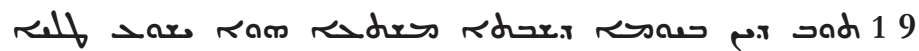

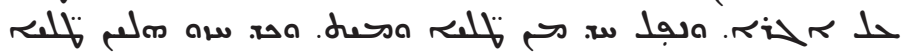
حiمه. (mo:wro 2

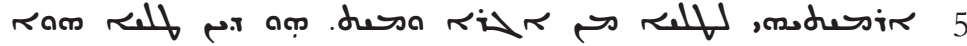

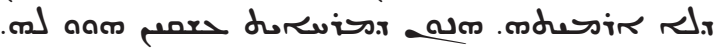

PMWG

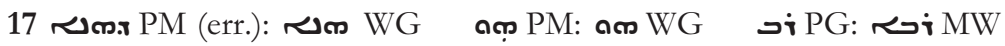

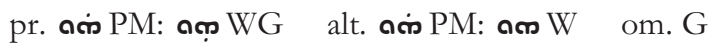

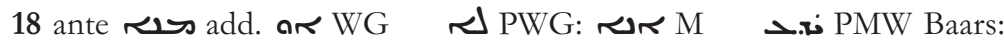
$\mathrm{G}$

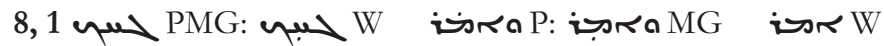

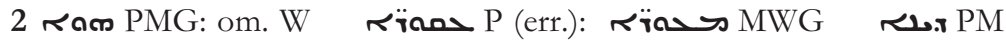
(err.): ז.ד Wh

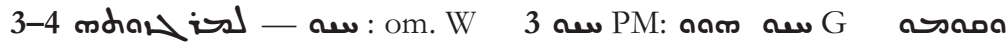

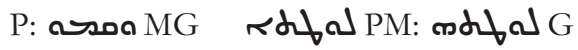

4 post mdan isladd. *GM

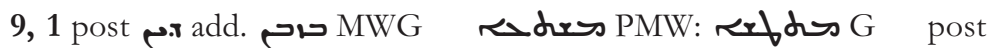

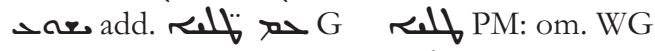

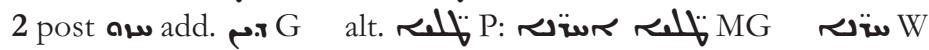

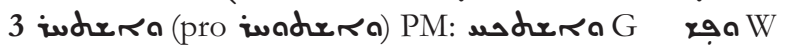

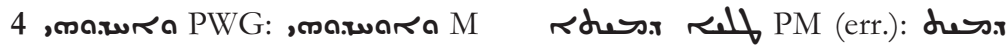

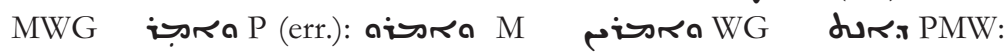
ז $G$

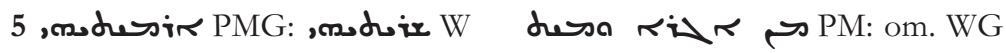

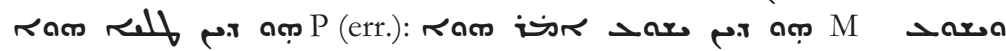

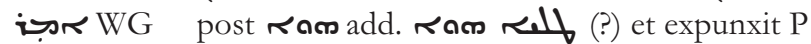

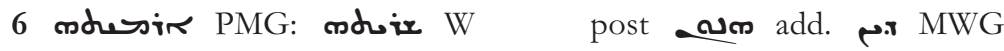

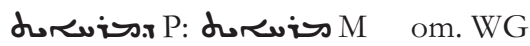


3 The boy Jesus answered and said to them"113: "Leave now, so that I may go down to the dead boy and I will ask him, and immediately he will declare to us the truth who really threw $<$ him $>114$ down." Then the boy Jesus came down. He stood above the corpse of the dead boy, and said in a loud voice115: "Zeno, Zeno"116 (for thus indeed was his name) "did I really throw you from the roof as your family is accusing me?" 117 But when that dead boy heard his voice, 118 immediately he leaped up and stood. He said before everyone ${ }^{119}$ : "No, my Lord."

4 All of them were amazed. Even the boy's parents who were accusing Jesus returned ${ }^{120}$ and were praising God for this wonder that had happened.

$11^{121} 1$ Again, when Jesus was seven years old, his mother sent him to fill ${ }^{122}$ water. And in the press of a great crowd, his pitcher struck [against something] and was broken.

\footnotetext{
113 Jesus' words here are not found in W and G nor any other witnesses.

$114 \mathrm{P}$ has a feminine object.

$115 \mathrm{~W}$ and $\mathrm{G}$ have: "Then he came down beside the dead one and said to him."

116 The boy's name is corrupt in $\mathrm{M}$.

${ }^{117} \mathrm{~W}$ and $\mathrm{G}$ (and all other witnesses) lack "as your family is accusing me."

$118 \mathrm{~W}$ and $\mathrm{G}$ (and all other witnesses) lack "when that dead boy heard his voice."

${ }^{119} \mathrm{~W}$ and $\mathrm{G}$ (and all other witnesses) lack "before everyone."

${ }^{120}$ Again, only P and M identify the family as those who accused him.

121 The Syriac and other early versions do not contain ch. 10. Gs places the episode between chs. 16 and 19.

122 G has "to draw."
} 
3 ل

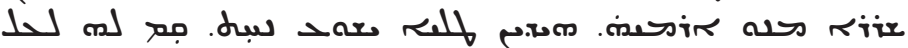

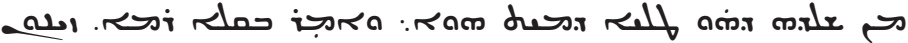

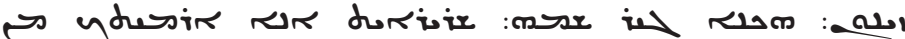

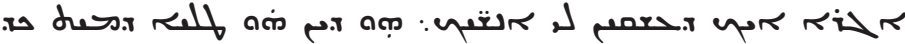

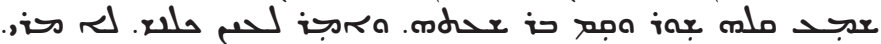
anm ansho 4

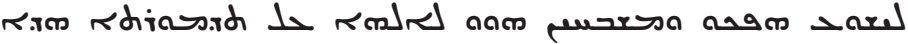

dians

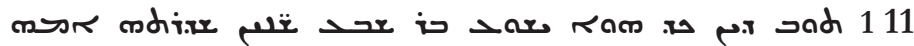

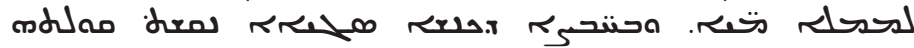
dirdidra

PMWG

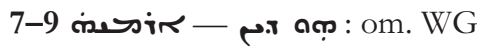

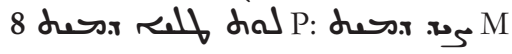

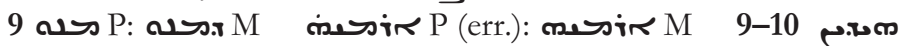

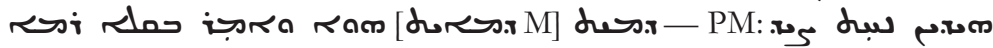

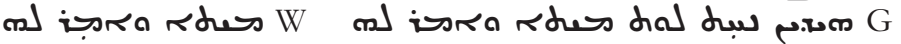

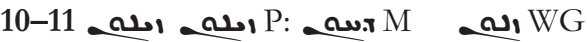

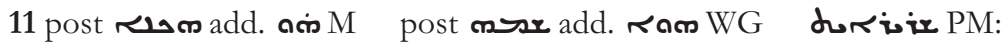

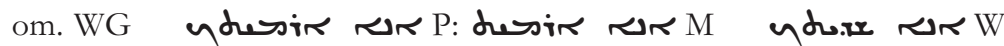

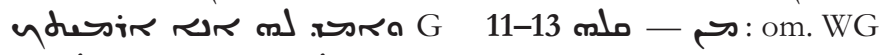

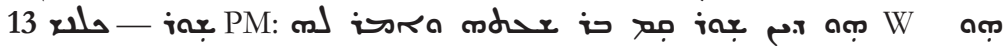

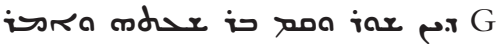

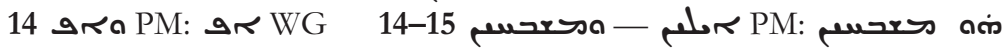
WG

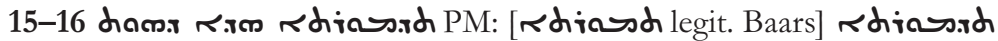

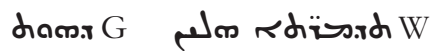

16 post dom radd. * MG

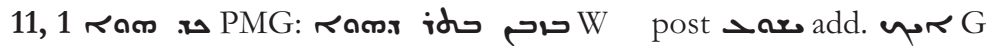

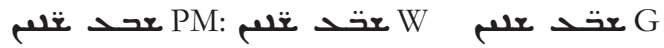

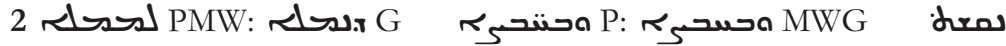
PMW Baars: دمعلd G

3 divddra PMW: dirdra G 
2 Then Jesus spread out the hood ${ }^{123}$ which was covering him and he collected the waters that had scattered from his pitcher and poured them in his hood. And carrying (?) and he came home.124 Then his mother Mary was astonished and she kept in her heart all these things that she was seeing. ${ }^{125}$

121 Once again Jesus was playing. He sowed a plant of wheat, ${ }^{126}$ and through it there was a great harvest. ${ }^{127}$

2 He harvested from them 128100 cors, and ${ }^{129}$ gave them to the people of the village.

131 Jesus was eight years old. Joseph was a carpenter and was making nothing other than ploughs and yokes. A man ordered from him a bed of six cubits. One plank ${ }^{130}$ did not have the (proper) length on one side, for it was shorter than the other.

123 W and G have "cloak." Several Sw Mss also have "hood."

${ }^{124} \mathrm{~W}$ and $\mathrm{G}$ shorten the two sentences to read: "he collected and brought (Wright adds: [home]) that water." The longer reading is found also in the Sw Ms Mingana Syr. 48. P and M's "carrying" (هحب) lacks an object, but it may be simply a corruption of sentence "and the boy came home."

$125 \mathrm{~W}$ has: "And his mother Mary was astonished at all that she was seeing," but the longer reading is supported by Gs, the early versions, Sw, and Se.

126 The complete sentence in W and G reads, "he sowed one measure of wheat."

127 The latter half of the sentence is unique to $\mathrm{P}$ and $\mathrm{M}$.

128 "From them" is unique to $\mathrm{P}$.

${ }^{129} \mathrm{M}$ begins the sentence here.

${ }^{130} \mathrm{P}$, along with W and G, reads ("side," fem.) whereas M has ช ("plank," masc.). The reading from P, W, and G is retained (but translated here as plank) because it appears to be original and is reflected in the feminine pronouns that follow. 
2

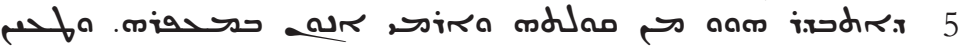

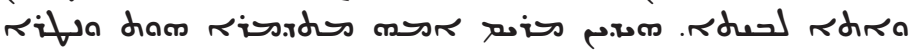

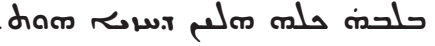
dans : rodia 112

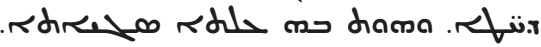

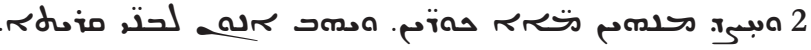

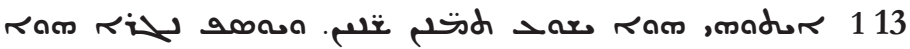

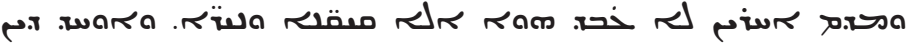

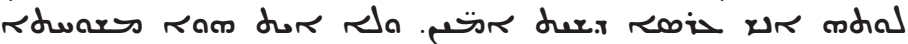

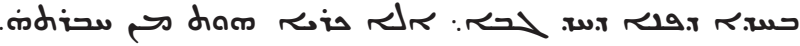

\section{PMWG}

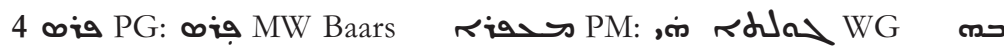

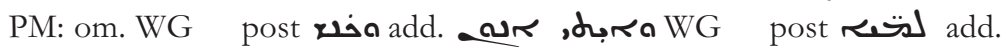
مाWG

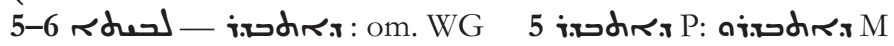

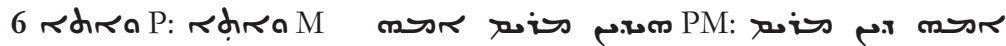
WG

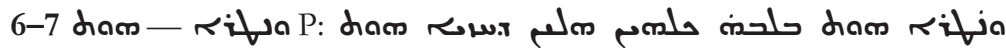

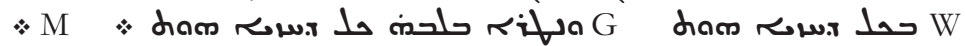

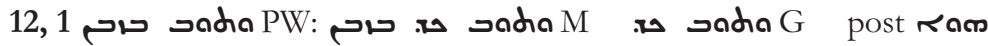

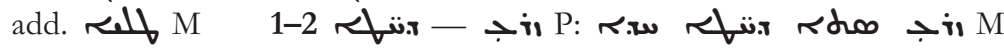

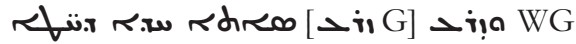

2 rdir- dinma P: om. MWG

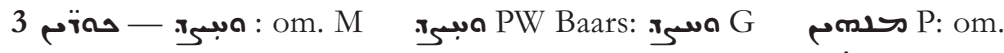

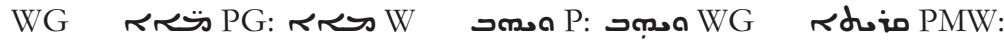

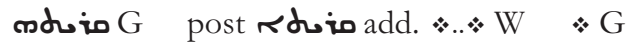

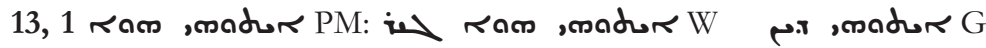

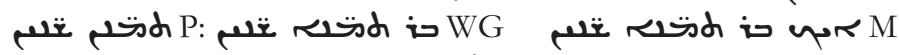

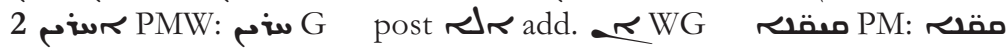

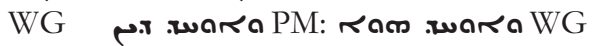

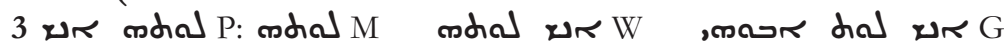

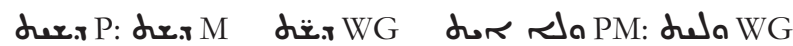
M כשז זפת : PWG 
The boy Jesus said to his father: "Take hold of the end of the one shorter than the other."'131

2 Jesus took the length of the wood and pulled and stretched the wood and made it equal to the other. Jesus said to Joseph: "Do henceforth what you wish."

$14^{132} 1$ When Joseph saw his intelligence, he wished to teach him learning, ${ }^{133}$ and brought $<$ him $>134$ to a scribe. ${ }^{135}$ That scribe answered ${ }^{136}$ and said to [Jesus]: "Say Aleph." And Jesus said: "Aleph."137 Again the scribe added that he should say to him, Beth. 2 Jesus < said $>138$ to him: "Tell me first what Aleph is, and then I will tell you ${ }^{139}$ Beth." 140 That scribe was furious and struck him, ${ }^{141}$ and immediately he fell down and died.

3 The boy Jesus went back to his family. Joseph called Mary his mother and commanded and said to her: "Do not permit him to go out of the house, so that those who strike him will not die."

${ }^{131} \mathrm{~W}$ and $\mathrm{G}$ lack this exchange but it is supported by Se and several versions (Gs, LM, and the related Irish Ms). Perhaps its absence is due to dittography (as a result of the repetition of "shorter than the other").

${ }^{132}$ This chapter is not found in G.

133 W has "writing." Gs, LV, and LM have "letters."

${ }_{134} \mathrm{P}$ has a feminine object.

135 W has "to the school" (or "to the home of a scribe").

${ }^{136} \mathrm{P}$ inserts here "and also" which is nonsense and is not found in the other Mss. The sentence in M reads: "He said to him," and in W: "The scribe said to him." This is similar to LV and Eth.

137 "Aleph" is lacking in $\mathrm{M}$ and W.

${ }^{138}$ P reads "says."

$139 \mathrm{~W}$ adds "about."

${ }^{140} \mathrm{Gs}$ and LV reverse the order of the letters. The exchange is missing in Eth.

${ }^{141}$ W has "took and struck him." 


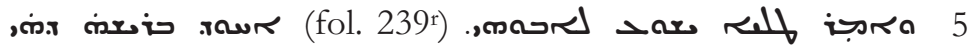

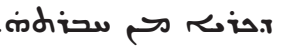

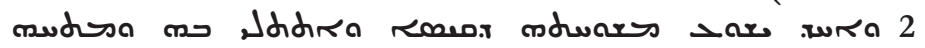

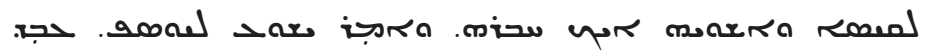

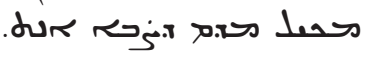

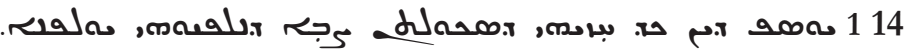

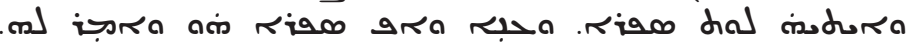
אדi حed 2 5

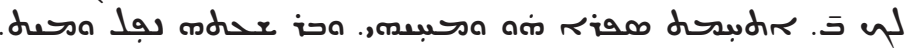
3

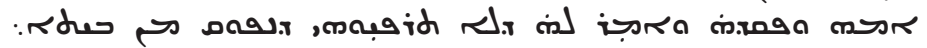

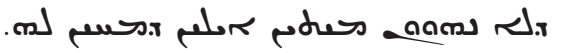

\section{PMWG}

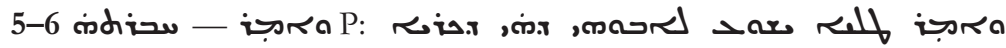
ח M $\mathrm{O}$ om. WG

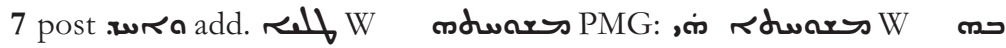

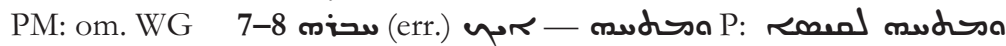
r ra का م

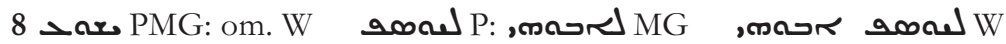

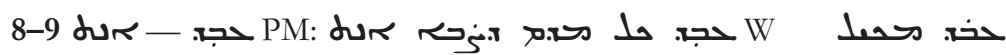

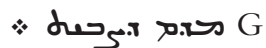

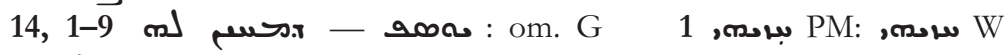
rala PM: مصن W

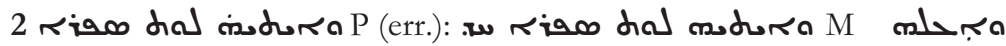

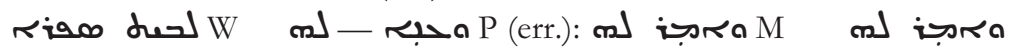
रांक W

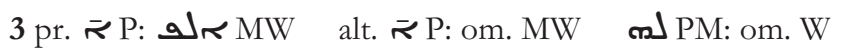

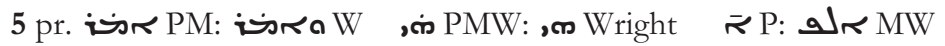

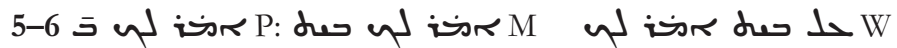

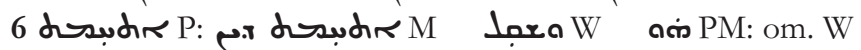

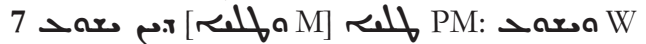

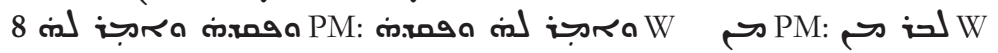


$15^{142} 1$ But another scribe said to Joseph"143: "Hand him over to me. I will teach him by flattery." 144

2 Jesus entered into [the house of] that scribe. ${ }^{145} \mathrm{He}$ took a scroll and was reading, not what was written, but he opened his mouth and spoke in the spirit, ${ }^{146}$ as that scribe wrote on the ground ${ }^{147}$ and it sprung up from him. ${ }^{148}$ Great crowds, hearing his words, assembled and stood there. Jesus thus opened his mouth and was speaking, so that all who arrived and stood there might be amazed and astonished.

3 When Joseph heard, he ran [and] came because he was afraid ${ }^{149}$ lest the scribe also would die. The scribe said to Joseph: "You have delivered to me not a student but a master."

4 And Joseph took Jesus and led him back to his home. ${ }^{150}$

161 Again Joseph sent his son James to cut down sticks. ${ }^{151}$ Jesus also went with him. While gathering sticks, a deadly ${ }^{152}$ viper bit James on his hand.

2 When Jesus came near to him, he did to him nothing

142 This chapter is absent in G.

143 M lacks "to Joseph."

${ }^{144}$ W lacks "by flattery," but the reading is supported by Gs, LM, Sw, and Se.

145 Perhaps ria dad should read ria

$146 \mathrm{~W}$ has "not what was written but great miracles" and the chapter ends here.

147 Sw reads "that scribe fell on the ground," which is consistent with Gs, Eth, and LM. M has the future form of the verb. Se has "that scribe, when he heard, went down and sat with him on the ground."

${ }^{148}$ For P's corrupt 'it sprung up from him' $M$ has 'he beseeched him,' which is consistent with Sw, Gs, Eth, and LM.

${ }^{149} \mathrm{P}$ has the perfect ("he had feared"); $\mathrm{M}$ has a participle ("fearing").

150 The later Greek Mss (and related versions) add an epilogue in which Jesus restores the teacher from ch. 14 to life.

$151 \mathrm{~W}$ and G have "to gather sticks," which is the more likely reading as $\mathrm{P}$ and $\mathrm{M}$ use the same verb shortly after.

152 W lacks "deadly." 


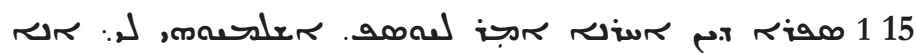

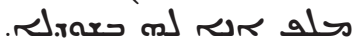

2 جل sam

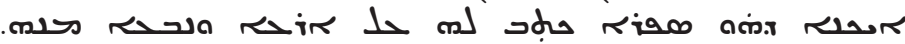

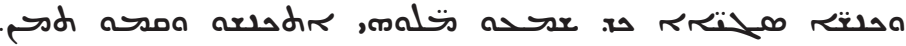

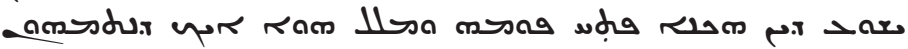

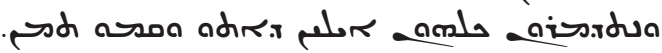
3 ror

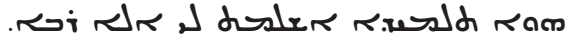
4

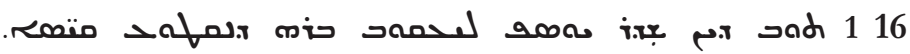

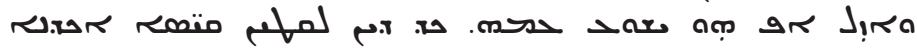

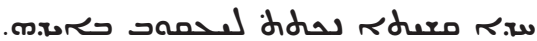
2 a ص. 2

PMWG

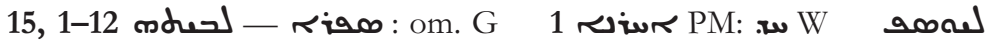

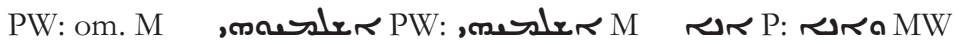
2 حra: OM. W

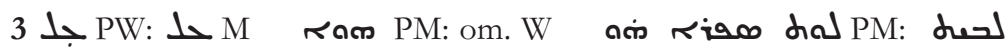

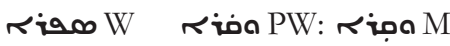

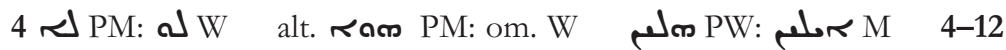

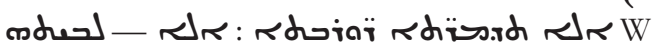

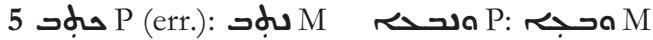

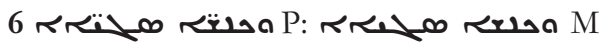

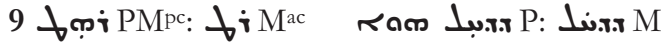

10 مr P: ara M dom P: om. M

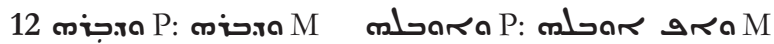

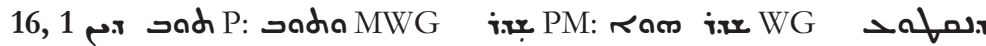
PM: הلمه

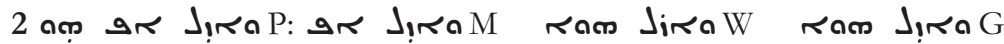

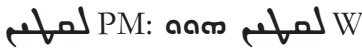

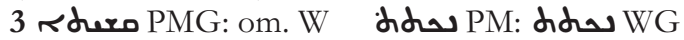

4 ardal PMG: al W 
more than stretch out his hand and blow on that bite. ${ }^{153}$ And ${ }^{154}$ the bite was healed, the viper died, and James lived. ${ }^{155}$

$19^{156} 1$ When he ${ }^{157}$ was twelve years old, they went to Jerusalem, as was custom for Joseph and Mary, to the festival of Passover. When Passover was completed, ${ }^{158}$ they returned to their home. When they had turned to come [home], Jesus remained in Jerusalem. His parents did not know that he stayed behind in Jerusalem, ${ }^{159}$ but they thought that he was with their companions.

2 When they came to the $<$ rendezvous $>160$ of that day, they were seeking him among

${ }^{153} \mathrm{P}$ has the verbs in the perfect.

154 G adds "immediately."

155 'The viper died, and James lived' is lacking in W and G, though it is supported by Sw, Se, and Gs, LM, and in part by Eth ("As for the serpent, it died immediately").

156 The Syriac and other early versions (including Gs) do not contain chs. 17 and 18.

$157 \mathrm{~W}$ and $\mathrm{G}$ have "Jesus."

${ }^{158} \mathrm{~W}$ and G have "when they had completed Passover."

${ }^{159} \mathrm{~W}$ and G have "neither Joseph nor his mother Mary knew (it)." M lacks the entire sentence. P's reading here, not found in Gs or Eth, may derive from a misreading of "nor Mary" with the similar looking "in Jerusalem." The misreading may also have led to the transformation of

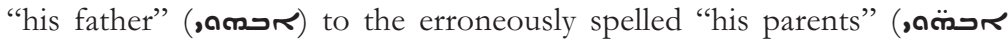

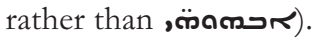

${ }^{160} \mathrm{P}$ and $\mathrm{M}$ have the corrupt reading rand ("to the inner room"). 


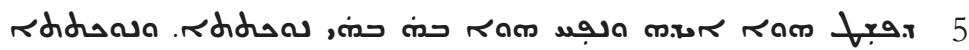

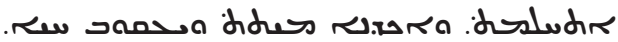

119

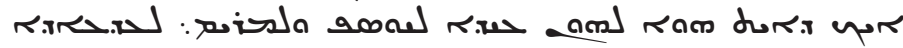

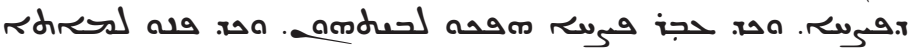

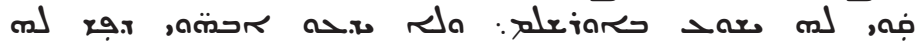
5

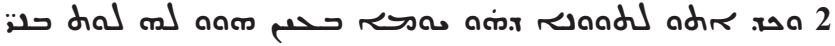

PMWG

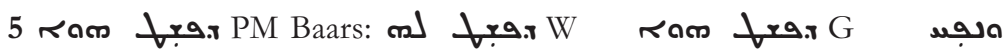

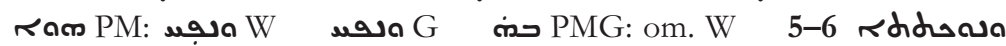

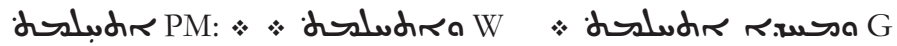

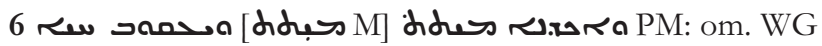

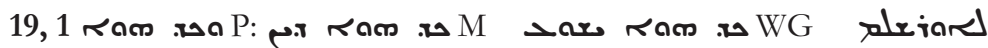

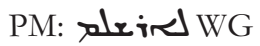

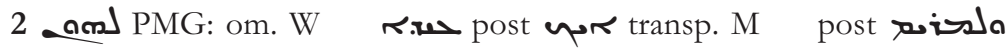

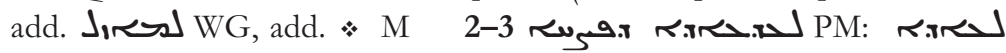

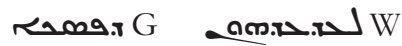

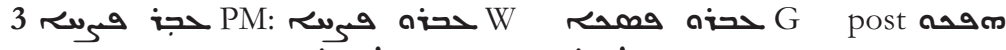

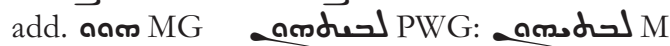

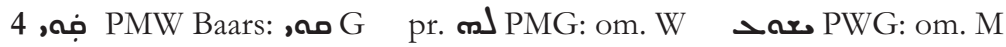

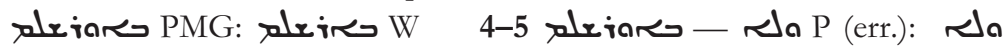

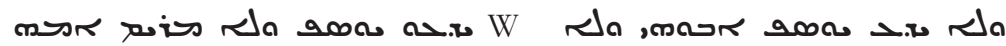
ת G $G$ om. M (homoeotel.)

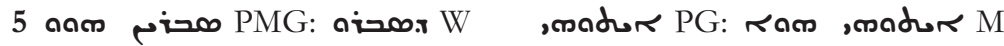
am W

6 randl PM (err.): שand WG 
their kinsfolk and among those who knew them. When they did not $<$ find him, they returned to Jerusalem and were seeking him. After three days $>161$ they found him in the temple, ${ }^{162}$ sitting among the teachers, and listening to them ${ }^{163}$ and questioning them. All those hearing were astonished at him, because he was silencing the elders and the teachers. ${ }^{164}$ And ${ }^{165}$ he was expounding to them the parables of the prophets and the mysteries and allegories of the law. 166

3 His mother < said $>167$ to him: "My son, why have you done this to us? Look, I and your father, with much anxiety, were searching for you. ${ }^{168}$ Jesus answered and said to her: "Why were you searching for me? Do you not know that it is fitting for me to be in my father's house?" 169

4 The scribes and the Pharisees answered and said to Mary: "Are you the mother of this boy? The Lord has blessed you in your fruit, ${ }^{170}$ for

161 The missing material is supplied here from M, W, and G. P's omission is likely due to homoeoteleuton.

162 "Temple" is not found in W and G but it is present in Gs, Eth, Sw, Se, and Old Syriac Luke.

$163 \mathrm{G}$ finishes the verse here.

164 W has only "those teachers." Gs has "elders," Eth has "priests."

165 W has "for."

${ }^{166} \mathrm{M}$ reads, "the parables and allegories of the prophets and mysteries and examples of the law."

167 P reads "says."

$168 \mathrm{M}, \mathrm{W}$, and G have: "for we were distressed and agitated and searching for you."

169 Jesus' response to his mother is lacking in G, likely due to homoeoarcton.

$170 \mathrm{~W}$ has only "The Lord has blessed you." P, M, and G's reading is supported by Sw, Gs ("Blessed are you because the Lord God has blessed the fruit of your womb") and Eth ("For you are blessed in your fruit"). 
ה...

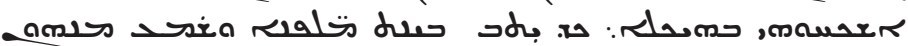

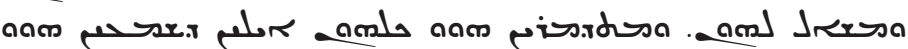

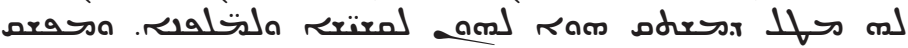

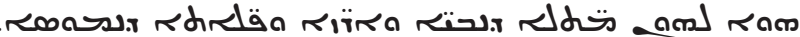

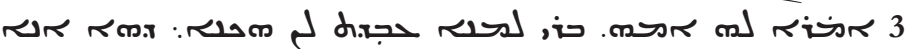

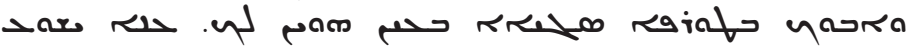

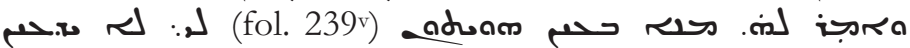
15

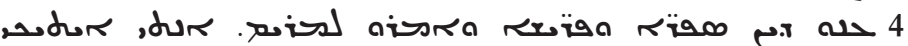

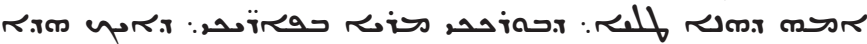

\section{PMWG}

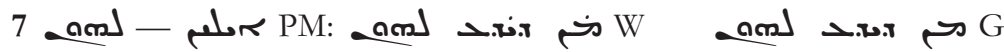

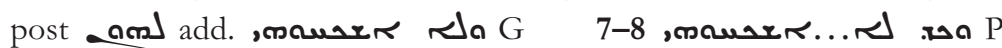

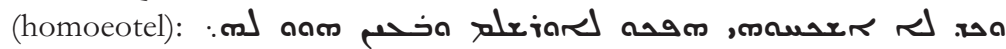

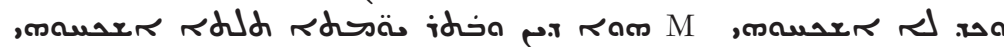

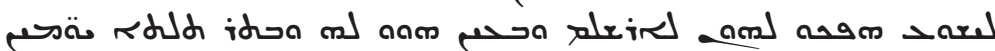

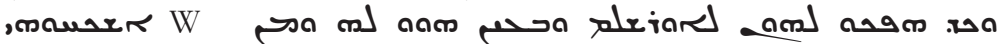

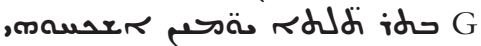

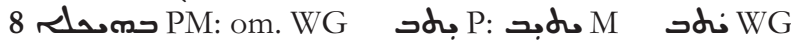

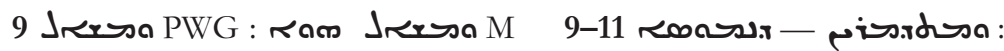

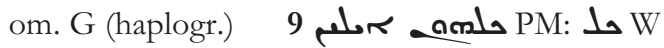

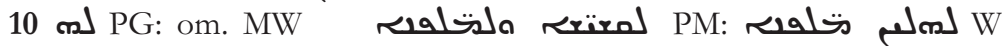
Drasa PM: ora W W

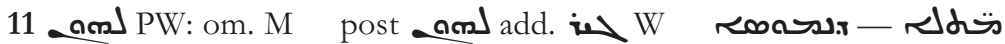
P: تخهلم

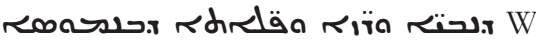

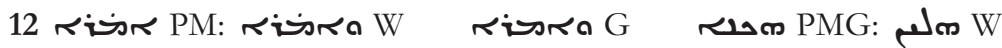

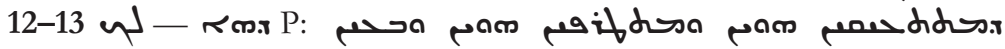

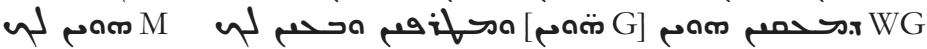

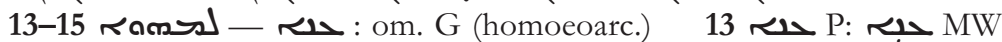
14 in PM: om. W

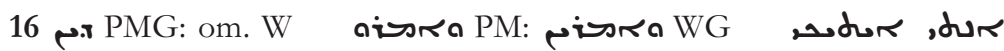

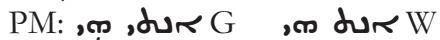

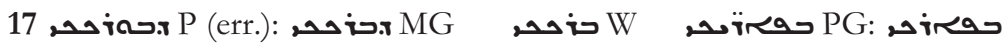

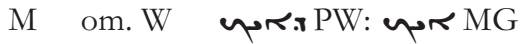


glory and ${ }^{171}$ wisdom such as this in children we have neither seen nor heard. ${ }^{172}$

$5 \mathrm{He}$ rose and went with them ${ }^{173}$ and he was listening to them ${ }^{174}$ and was obedient to his parents. ${ }^{175}$ But $<$ his $>176$ mother was preserving all these words in her heart 177 and she was contemplating [them?]. ${ }^{178}$ Jesus was growing and excelling and advancing in wisdom and stature and grace ${ }^{179}$ before God and before men.

Glory to him and his mercy upon us forever and ever, amen. ${ }^{180}$

$171 \mathrm{~W}$ and G have "of."

$172 \mathrm{~W}$ and $\mathrm{G}$ add "that anyone has spoken." This addition is lacking also in Sw.

173 W has "with his mother."

174 "And he was obedient to them" is lacking in M, W, G, and Sw.

175 W has "to them."

$176 \mathrm{P}$ has a feminine pronoun.

177 W lacks "in her heart," as does Old Syriac Luke. The reading is supported by Gs, Eth, and Sw. The entire sentence is lacking in G.

178 This last, troubling clause is found only in P.

179 This sentence is presented in a variety of ways in the Mss. M lacks "growing," W has "Jesus was excelling and advancing in wisdom and grace," and G has "Jesus was excelling and growing in wisdom and stature and grace."

$180 \mathrm{~W}$ and $\mathrm{G}$ have instead the title: "Here (ends) the Childhood of our Lord Jesus (G adds: Messiah)." M reads only "Glory to him, amen." 


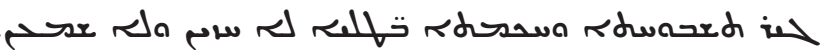

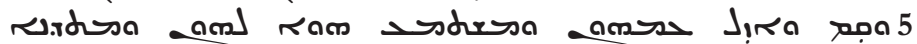

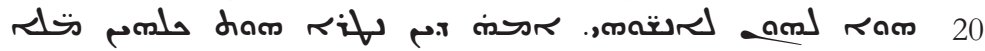

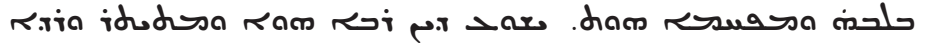

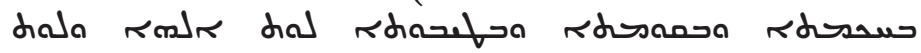
حانصrم.

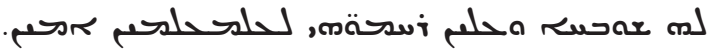

\section{PMWG}

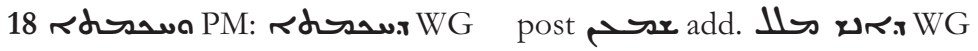

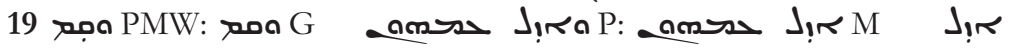

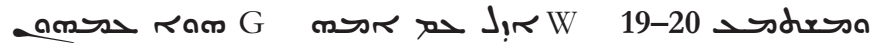

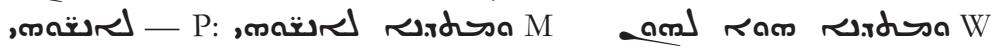
את : : : om. G

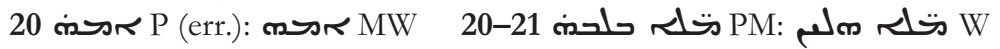
21 dam

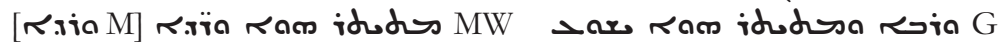

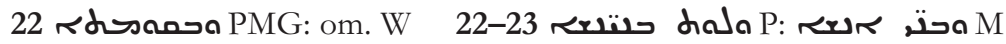

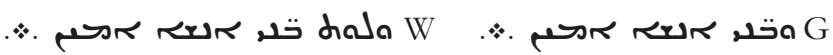

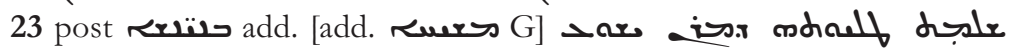
WG

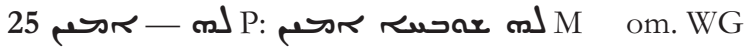


